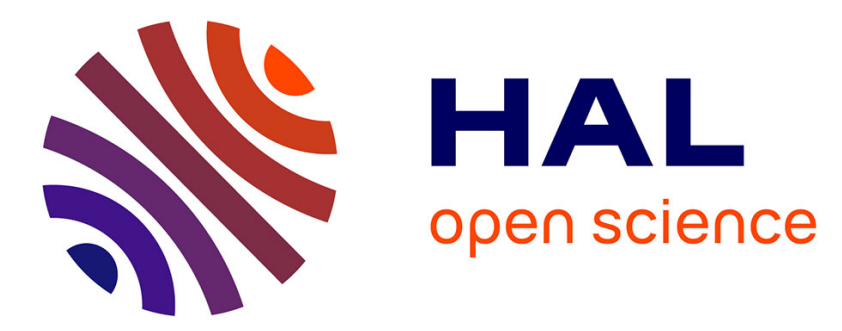

\title{
Selective catalytic reduction of NO by NH3 on cerium modified faujasite zeolite prepared from aluminum scraps and industrial metasilicate
}

\author{
Rahma Abid, Gérard Delahay, Hassib Tounsi
}

\section{- To cite this version:}

Rahma Abid, Gérard Delahay, Hassib Tounsi. Selective catalytic reduction of NO by NH3 on cerium modified faujasite zeolite prepared from aluminum scraps and industrial metasilicate. Journal of Rare Earths, 2020, 38 (3), pp.250-256. 10.1016/j.jre.2019.09.005 . hal-02483220

\author{
HAL Id: hal-02483220 \\ https://hal.science/hal-02483220
}

Submitted on 26 Nov 2020

HAL is a multi-disciplinary open access archive for the deposit and dissemination of scientific research documents, whether they are published or not. The documents may come from teaching and research institutions in France or abroad, or from public or private research centers.
L'archive ouverte pluridisciplinaire HAL, est destinée au dépôt et à la diffusion de documents scientifiques de niveau recherche, publiés ou non, émanant des établissements d'enseignement et de recherche français ou étrangers, des laboratoires publics ou privés. 


\title{
Selective catalytic reduction of $\mathrm{NO}$ by $\mathrm{NH}_{3}$ on cerium modified faujasite
}

\section{zeolite prepared from aluminum scraps and industrial metasilicate}

\author{
RahmaAbid $^{1}$, Gérard Delahay ${ }^{2}$, HassibTounsi $^{1}$ \\ ${ }^{1}$ Laboratoire des matériaux avancés, Ecole Nationale d'Ingénieurs de Sfax, Université de Sfax, TUNISIE. \\ ${ }^{2}$ Institut Charles Gerhardt, CNRS/UM/ENSCM, Equipe "Matériaux Avancés pour la Catalyse et la Santé", \\ Ecole Nationale Supérieure de Chimie de Montpellier, 240 av. du Professeur Emile Jeanbrau, 34296 \\ Montpellier cedex, France
}

\begin{abstract}
This work was devoted to the study of the selective catalytic reduction of $\mathrm{NO}$ by $\mathrm{NH}_{3}$ on calcined and hydrothermal treated cerium loaded zeolite catalysts. The parent faujasite zeolite $\mathrm{Na}-\mathrm{F}\left(\mathrm{Si} / \mathrm{Al}=1.32\right.$ and $\left.\mathrm{S}_{\mathrm{BET}}=749 \mathrm{~m}^{2} / \mathrm{g}\right)$ used as support for the preparation of the catalysts was obtained from industrial sodium metasilicate and aluminum scraps. As expected, the NO conversion increased with increasing the percentage of cerium in the structure of the faujasite zeolite. Total $\mathrm{NO}$ conversion into $\mathrm{N}_{2}$ was reached at $400^{\circ} \mathrm{C}$ at a space velocity of $250,000 \mathrm{~h}^{-1}$. The high conversion is due to the redox shift between $\mathrm{Ce}^{3+} / \mathrm{Ce}^{4+}$ and the strong acid sites related to the rare earth present in the framework that is the key in SCR of NO process. Moreover, the highest loaded cerium catalyst retained high almost its activity after thermal hydrotreatment at $850^{\circ} \mathrm{C}$. This higher loading is desirable for both activity and stability provided that two stages of preparation are used to put the Ce ions in the sodalite cages.
\end{abstract}

Keywords: Aluminum Scraps, $\mathrm{Ce}-\mathrm{Y}, \mathrm{NH}_{3}-\mathrm{SCR}$, Hydrothermal stability.

\section{Introduction}

The nitrogen oxide NO is a harmful gas which is produced during combustion of fossil fuels at high temperatures. It is essentially issued from mobile or stationary sources by oxidation of the nitrogen of the air. The major sources that produce NO are the fossil fuels like coal in the electrical power plants or fuels in the engines of gasoline and diesel cars[1]. NO is harmful to health and environment; it contributes to death and serious respiratory illness like asthma, 
chronic bronchitis [2], [3]. Furthermore, NO acidifies surface water (acid rain) reducing biodiversity and killing fishes. It is also damage forest ecosystem and contribute to the decreaseofvisibility by the formation of the "'smog"'. For these reasons, the emissions of NO must be limited.

The NO molecule is thermodynamically unstable. Nevertheless, it does not decompose because of its high activation energy $(364 \mathrm{~kJ} / \mathrm{mol})$. Thus, a catalyst must be used to facilitate its decomposition and reduced it to $\mathrm{N}_{2}$ and water $[4,5]$. The oxygen produced from the decomposition of NOor the gaseous mixture strongly adsorbed on the active sites of catalyst which causes their poisoning[5]. To avoid this inhibiting effect on the transformation rate of $\mathrm{NO}$, it is necessary to work in the presence of reducing agents like $\mathrm{H}_{2}, \mathrm{NH}_{3}$, hydrocarbon (HC) $[6,7]$.The most common technology in the elimination of NO is the selective catalytic reduction of $\mathrm{NO}$ by $\mathrm{NH}_{3}\left(\mathrm{NH}_{3}-\mathrm{SCR}\right)$. Two main types of catalysts are commercially used for this technology: $\mathrm{V}_{2} \mathrm{O}_{5}-\mathrm{WO}_{3} / \mathrm{TiO}_{2}$ and $\mathrm{Cu}$,Fe-zeolites. For the former type of catalyst, vanadium, which is toxic sublimes at high at high temperature. Moreover, it shows high oxidation of $\mathrm{SO}_{2}$ to $\mathrm{SO}_{3}$ which leads to decrease the activity and selectivity of $\mathrm{NO}_{\mathrm{x}}$ at $400^{\circ} \mathrm{C}[8-10]$. For these reasons, copper and iron exchanged zeolites have been developed and are preferred for mobile Diesel sources [11-13]. In the last decades, the cerium-catalysts were investigated in the $\mathrm{NH}_{3}-\mathrm{SCR}$ of $\mathrm{NO}$ because of its redox property $\left(\mathrm{Ce}^{3+}\right.$ to $\left.\mathrm{Ce}^{4+}\right)$ that promotes the activation of reactants on the surface of the catalysts[14, 15]. The redox shift between $\mathrm{Ce}^{4+}$ and $\mathrm{Ce}^{3+}$ of $\mathrm{CeO}_{2}$ can promote $\mathrm{NO}$ oxidation to $\mathrm{NO}_{2}$, which is beneficial to the $\mathrm{NH}_{3}-\mathrm{SCR}$ reaction[16]. As such, $\mathrm{CeO}_{2}$ has been widely used as key component of selective catalytic reduction catalyst for $\mathrm{NO}_{\mathrm{x}}$ removal such as $\mathrm{CeO}_{2} / \mathrm{TiO}_{2}[17]$, $\mathrm{CeO}_{2} / \mathrm{Al}_{2} \mathrm{O}_{3}$ [18], $\mathrm{CeO}_{2} /$ zeolite[19], $\mathrm{Mn}-\mathrm{Ce} / \mathrm{TiO}_{2}$ [20]. It had been reported that ceria based catalyst has great resistance to $\mathrm{SO}_{2}$ and $\mathrm{H}_{2} \mathrm{O}$ poisoning in the $\mathrm{NH}_{3}-\mathrm{SCR}$ reaction[21]. Wang et al. [22] investigated the influence of cerium precursor in the $\mathrm{NH}_{3}-\mathrm{SCR}$ of $\mathrm{NO}$ at low 
temperature. They found that the catalyst prepared from $\mathrm{Ce}\left(\mathrm{NO}_{3}\right)_{3} \cdot 6 \mathrm{H}_{2} \mathrm{O}$ precursor $(\mathrm{Ce}-\mathrm{NO}-$ R) with nanorods morphology exhibits higher $\mathrm{NO}_{\mathrm{x}}$ conversion and superior $\mathrm{SO}_{2} / \mathrm{H}_{2} \mathrm{O}$ resistance. Zhang et al. [23] studied the ceria loaded zirconium phosphate catalysts in $\mathrm{NH}_{3}$ SCR. They found that the addition of $20 \mathrm{wt} \%$ ceria to zirconium phosphate catalyst exhibited more than $98 \% \mathrm{NO}_{\mathrm{x}}$ conversion and $98 \% \mathrm{~N}_{2}$ selectivity in a wide temperature window of $250-425^{\circ} \mathrm{C}[23]$. Carja et al. [24] studied the reduction of $\mathrm{NO}$ by $\mathrm{NH}_{3}$ on $\mathrm{Mn}$ Ce/ZMS-5 catalysts which present NO conversion about $75-100 \%$ in the temperature range of $244-550{ }^{\circ} \mathrm{C}$. The work reported by Qi et al. [25] demonstrated a good NO conversion at $120^{\circ} \mathrm{C}$ of $\mathrm{MnOx}-\mathrm{CeO}_{2}$ catalyst. Wu et al. [26] showed that the introduction of cerium on $\mathrm{MnO}_{\mathrm{x}} / \mathrm{TiO}_{2}$ catalyst leads to steady $\mathrm{NO}$ conversion of $84 \%$ in the presence of $\mathrm{SO}_{2}$ for 6.5hours in the reaction stream. Compared to $\mathrm{MnO}_{\mathrm{x}} / \mathrm{TiO}_{2}$ catalyst, there is a largely decrease of NO conversion to $30 \%$.

In this work, the reduction of $\mathrm{NO}$ by $\mathrm{NH}_{3}$ on fresh and hydro-treated cerium-Faujasite zeolite catalysts was investigated. The parent zeolite $\mathrm{Na}-\mathrm{F}\left(\mathrm{Si} / \mathrm{Al}=1.32\right.$ and $\left.\mathrm{S}_{\mathrm{BET}}=749 \mathrm{~m}^{2} / \mathrm{g}\right)$ used as support for the preparation of catalysts was obtained from industrial sodium metasilicate and aluminum scraps. Moreover a large part of this study was devoted to the characterization of fresh and hydro-treated cerium-Faujasite zeolite catalysts by different techniques (XRD, FTIR, BET, UV-vis and $\mathrm{H}_{2}$-TPR)

\section{Experimental}

\subsection{Materials}

Industrial sodium metasilicate $\left(\mathrm{Na}_{2} \mathrm{SiO}_{3} \cdot 5 \mathrm{H}_{2} \mathrm{O}\right.$, PQ CORPORATION) was used as silicon source for the preparation of the FAU zeolite. The aluminum source's was aluminum scraps collected from metal manufacturing industry in the region of $\operatorname{Sfax}(\mathrm{Al}=99.77 \% \pm 0.02, \mathrm{Fe}=$ $0.207 \pm 0.006$ and $\mathrm{Cu}=0.008 \pm 0.001)$. The other chemical products are sodium hydroxide 
pellets (NaOH, Sigma Aldrich 99\% purity) and cerium (III) chloride heptahydrate $\mathrm{CeCl}_{3} .7 \mathrm{H}_{2} \mathrm{O}$ (Sigma Aldrich 99, 99\%).

\subsection{Preparation of the zeolitc support}

Firstly, $\mathrm{NaOH}$ pellets were dissolved in the required quantity of distilled water. Then the alkaline solution was divided to equal volumes in polypropylene bottles. The desired quantity of aluminum scraps was dissolved in one half of hydroxide solution volume and then filtered to remove the impurities. The silicon sources was added to the other half of hydroxide solution volume and mixed in capped bottle until clear. In order to obtain the aluminosilicate hydrogel, the silicon solution was poured to the aluminum solution quickly. The obtained thickly gel was stirred during a period of $10 \mathrm{~min}$ and then was aged for $14 \mathrm{~h}$ at room temperature (RT). Finally, the aged gel was heated at $80^{\circ} \mathrm{C}$ for 6 and 24 hours. After the crystallization was achieved, the obtained solids were filtered, washed with distilled water until $\mathrm{pH}$ around 9 , and then dried at $80^{\circ} \mathrm{C}$ for $24 \mathrm{~h}$.

\subsection{Preparation of the catalysts}

Cerium-zeolite faujasite (Ce-F) catalysts were prepared by ionic exchange method in aqueous solution by varying the concentration of cerium chloride: $0.02 \mathrm{M} ; 0.01 \mathrm{M}$ and $0.005 \mathrm{M}$. The required amount of cerium chloride was dissolved in $50 \mathrm{~mL}$ of distilled water and then $1 \mathrm{~g}$ of Na-F zeolite were added to the solution and mixed for $5 \mathrm{~h}$ at $50{ }^{\circ} \mathrm{C}$. The slurry was then centrifugated, washed three times with distilled water to remove the non-exchanged cerium and adsorbed chlorides on the surface of the zeolite. The recovered solids were dried for $24 \mathrm{~h}$ at $80{ }^{\circ} \mathrm{C}$ and then calcined for 1 hour at $450{ }^{\circ} \mathrm{C}$. The obtained catalysts were called $\mathrm{Ce}(\mathrm{x})-\mathrm{F}$, with $\mathrm{x}$ the cerium amount in $\mathrm{wt} \%$.

Another catalyst called $\mathrm{Ce}(20)-\mathrm{F}_{\mathrm{C}}$ was also prepared using $0.02 \mathrm{M}$ of cerium chloride solution. Nevertheless, after drying at $80^{\circ} \mathrm{C}$, the powder was calcined for 1 hour at $750{ }^{\circ} \mathrm{C}$ to 
ensure the siting of cerium in the sodalite cages. Finally, it was exchanged another time with $0.02 \mathrm{M}$ of cerium chloride solution and then calcined for 1 hour at $450{ }^{\circ} \mathrm{C}$.

\subsection{Characterization and analysis}

The obtained samples were characterized by a variety of conventional techniques. Powder Xray diffraction (XRD) patterns were obtained using D8 ADVANCE BRUKER $40 \mathrm{Kv}$ with $\mathrm{Cu}$ $\mathrm{K} \alpha$ radiation. The diffraction pattern was collected in the $2 \theta$ range of $5-50^{\circ}$ at a scan speed of $0.02^{\circ}$. The prepared zeolite was compared with a commercial Na-Y zeolite (Aldrich, cat. no $33,444-8$, lot $06402 \mathrm{LR}, \mathrm{Si} / \mathrm{Al}=2.5$ ). Infrared spectra were scanned from 400 to $4000 \mathrm{~cm}^{-1}$ using the FourierTransform infrared model Perkin Elmer spectrum BX spectrometer. The scanning electron microscopy (SEM) images were taken on a Hitachi S 4800 operated at $5 \mathrm{Kv}$. The BET surface areas $\left(\mathrm{S}_{\mathrm{BET}}\right)$ and pore size distributions were determined by nitrogen adsorption-desorption on an ASAP2020 instrument (Micromeritics Instrument Corporation, GA. Prior to these measurements, the samples were degassed at $250{ }^{\circ} \mathrm{C}$ in vacuum.Thermogravimetric analysis (TGA) experiments were carried out on Perkin Elmer Simultaneous Thermal Analyser STA 6000 under anair at a flow rate of $100 \mathrm{~cm}^{3} \mathrm{~min}^{-1}$. The temperature increased from 30 to $900{ }^{\circ} \mathrm{C}$ at a rate of $10{ }^{\circ} \mathrm{C} / \mathrm{min} . \mathrm{H}_{2}$-TPR studies were conducted on a MicromeriticsAutochem 2910 instrument. $80 \mathrm{mg}$ of oven dried sample was placed in one arm of a U-shaped quartz tube on quartz wool. Prior to TPR, the catalysts samples were pretreated with $20 \% \mathrm{O}_{2} / \mathrm{N}_{2}$ at $550 \circ \mathrm{C}$ for $30 \mathrm{~min}\left(10^{\circ} / \mathrm{min}\right)$ to remove the water present, then are cooled in air at $50^{\circ} \mathrm{C}$. The TPR analysis was carried out in a reducing mixture consisting of $3 \% \mathrm{H}_{2} / \mathrm{Ar}$ and heated from 50 to $800^{\circ} \mathrm{C}\left(10{ }^{\circ} \mathrm{C} / \mathrm{min}\right)$. UV/Vis diffuse reflectance spectra were collected by Lambda 40 Perkin spectrometer.

The $\mathrm{NH}_{3}-\mathrm{SCR}$ of $\mathrm{NO}$ catalytic test was performed in temperature programmed surface reaction (TPSR, $\left.5^{\circ} \mathrm{C} / \mathrm{min}\right)$ ) using a flow reactor operating at atmospheric pressure with a 
space velocity of $250,000 \mathrm{~h}^{-1}$. The catalyst sample $(24 \mathrm{mg})$ was putted in quartz reactor positioned between two layers of inert quartz wool. The reactant gas composition was adjusted to 1000ppm NO, 1000ppm $\mathrm{NH}_{3}, 8 \% \mathrm{O}_{2}, 3.5 \% \mathrm{H}_{2} \mathrm{O}$ and balance with helium.

Hydrothermal treatment of catalysts was carried out in quartz fixed-bed microreactor. However, $1 \mathrm{~g}$ of catalyst was placed in the reactor and heated to the desired temperature in flowing $20 \% \mathrm{O}_{2} / \mathrm{He}$. Then water is injected by circulating the airflow through a bubbler containing deionized water at $47{ }^{\circ} \mathrm{C}\left(10 \% \mathrm{H}_{2} \mathrm{O}\right.$ vapour $)$ during 4 hours. All gas lines were heated to prevent water condensation. Four different hydrothermal temperatures were used: $700^{\circ} \mathrm{C}$ (ht 700 ), $800^{\circ} \mathrm{C}$ (ht 800 ), $850^{\circ} \mathrm{C}$ (ht 850 ) and $900^{\circ} \mathrm{C}$ (ht 900). The resulting solids were labeled $\mathrm{Cu}(\mathrm{x})-\mathrm{F}$ ht $\mathrm{XXX})$.

\section{Results and discussions}

3.1. Characterization of the prepared zeolitesErreur! Nous n'avons pas trouvé la source du renvoi.The molar composition of the starting gel used to study the effect of crystallization time is the following: 5.19 $\mathrm{Na}_{2} \mathrm{O}: \mathrm{Al}_{2} \mathrm{O}_{3}: 2.9 \mathrm{SiO}_{2}: 182.76 \mathrm{H}_{2} \mathrm{O}$. After aging for 14 hours at room temperature, the gel was crystallized at $80^{\circ} \mathrm{C}$ for 6 and 24 hours.

Figure 1 shows the XRD patterns of the obtained solids at $80^{\circ} \mathrm{C}$ for $6 \mathrm{~h}\left(\mathrm{Na}-\mathrm{F}_{6 \mathrm{~h}}\right)$ and $24 \mathrm{~h}\left(\mathrm{Na}-\mathrm{F}_{24 \mathrm{~h}}\right)$. After $6 \mathrm{~h}$ of crystallization, one can see fine diffraction peaks characteristic of the FAU zeolite. The increase of the crystallization time to $24 \mathrm{~h}$, there is an increase of the intensity of the peaks. 
In table 2, we reported the chemical analysis of the two samples $\mathrm{Na}-\mathrm{F}_{6 \mathrm{~h}}$ and $24 \mathrm{~h} \mathrm{Na}-$ $\mathrm{F}_{24 \mathrm{~h}}$ performed by EDS in five different spots. The $\mathrm{Si} / \mathrm{Al}$ molar ratios of the two samples are comparable; $\mathrm{Si} / \mathrm{Al}=1.27$ for $\mathrm{Na}-\mathrm{F}_{6 \mathrm{~h}}$ and $\mathrm{Si} / \mathrm{Al}=1.32$ for $24 \mathrm{~h} \mathrm{Na}-\mathrm{F}_{24 \mathrm{~h}}[27]$.

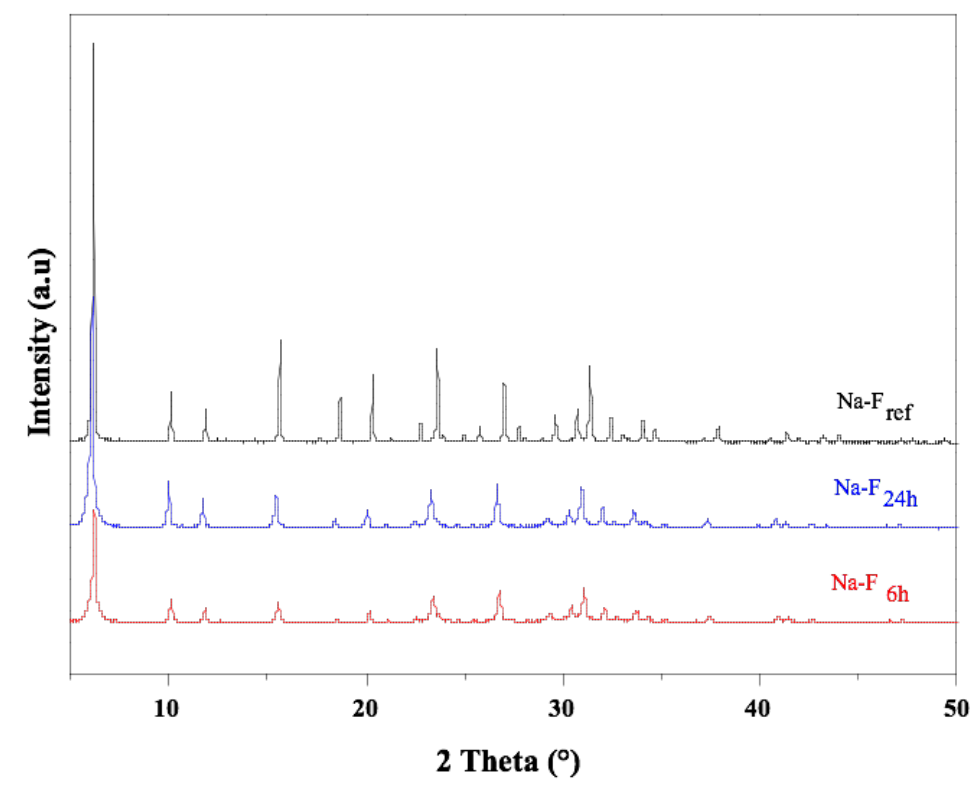

Figure 1 : XRD of $\mathrm{Na}-\mathrm{F}_{6 \mathrm{~h}}, \mathrm{Na}-\mathrm{F}_{24 \mathrm{~h}}$ prepared at $80^{\circ} \mathrm{C}$ for 6 and 24 hours, respectively.

Table1 : Chemical analysis of $\mathrm{Na}-\mathrm{F}_{6 \mathrm{~h}}, \mathrm{Na}-\mathrm{F}_{24 \mathrm{~h}} \mathrm{Samples}$ performed with EDS.

\begin{tabular}{lcccc}
\hline Samples & Na (wt. \%) & Al (wt.\%) & Si (wt. \%) & Si/Al (mol/mol) \\
\hline Na-F $_{\text {6h }}$ & 19.62 & 35.26 & 46.74 & 1.27 \\
Na-F $_{\text {2h }}$ & 21.07 & 33.95 & 46.97 & 1.32 \\
\hline
\end{tabular}

The SEM micrographs of Na-F24h (A1, A2) were displayed in Figure 2. The micrographs showed some crystals fused together forming agglomerate particles. Moreover, the particle size of isolated crystals was less $1 \mu \mathrm{m}$. It can be seen from the image that the catalyst shows perfect degree of crystallization which is in accordance with the XRD results ( 
Figure 1). In the rest of the work we use the sample $\mathrm{Na}-\mathrm{F}_{24 \mathrm{~h}}$ and it will be named Na-F. 


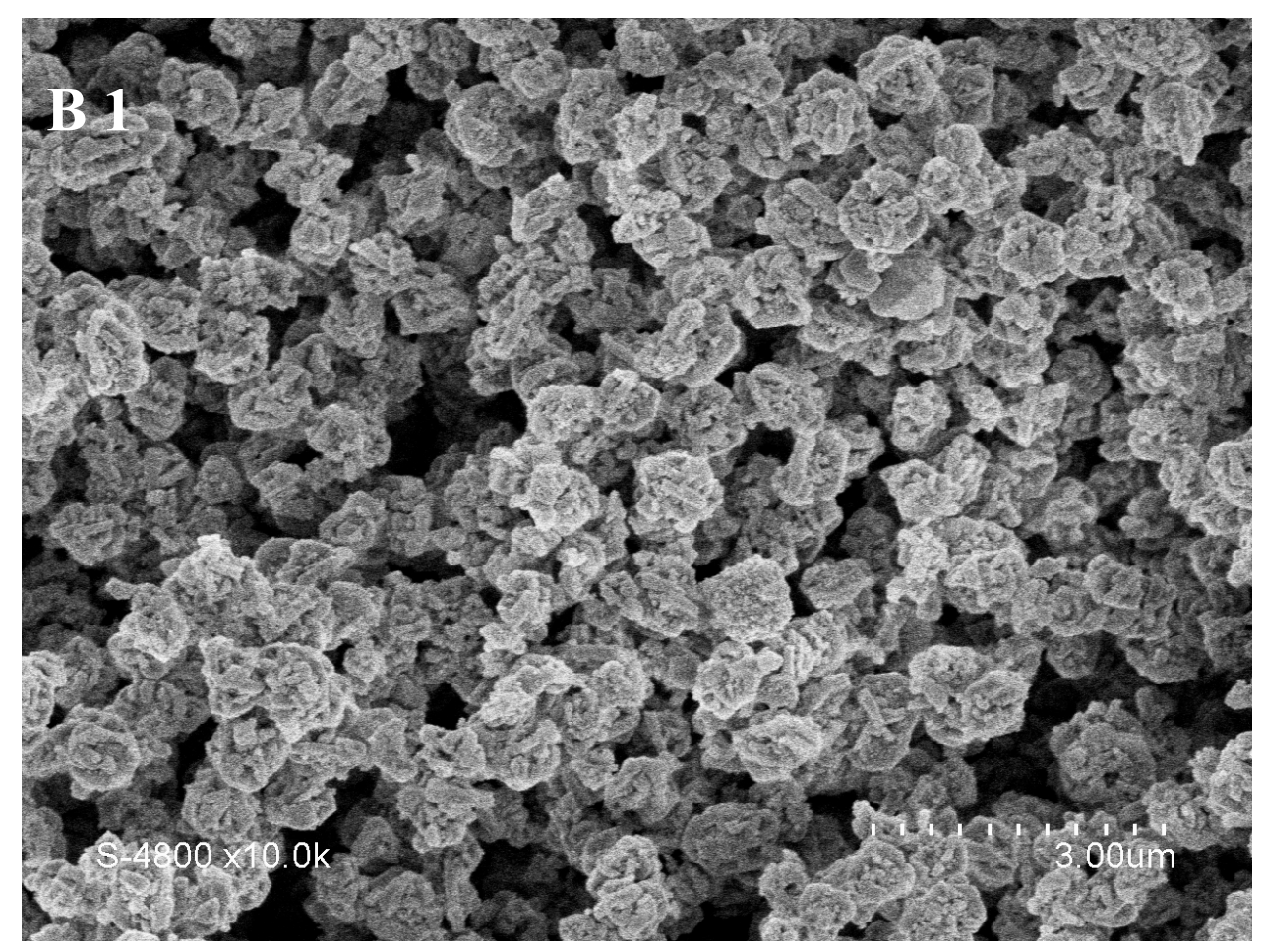



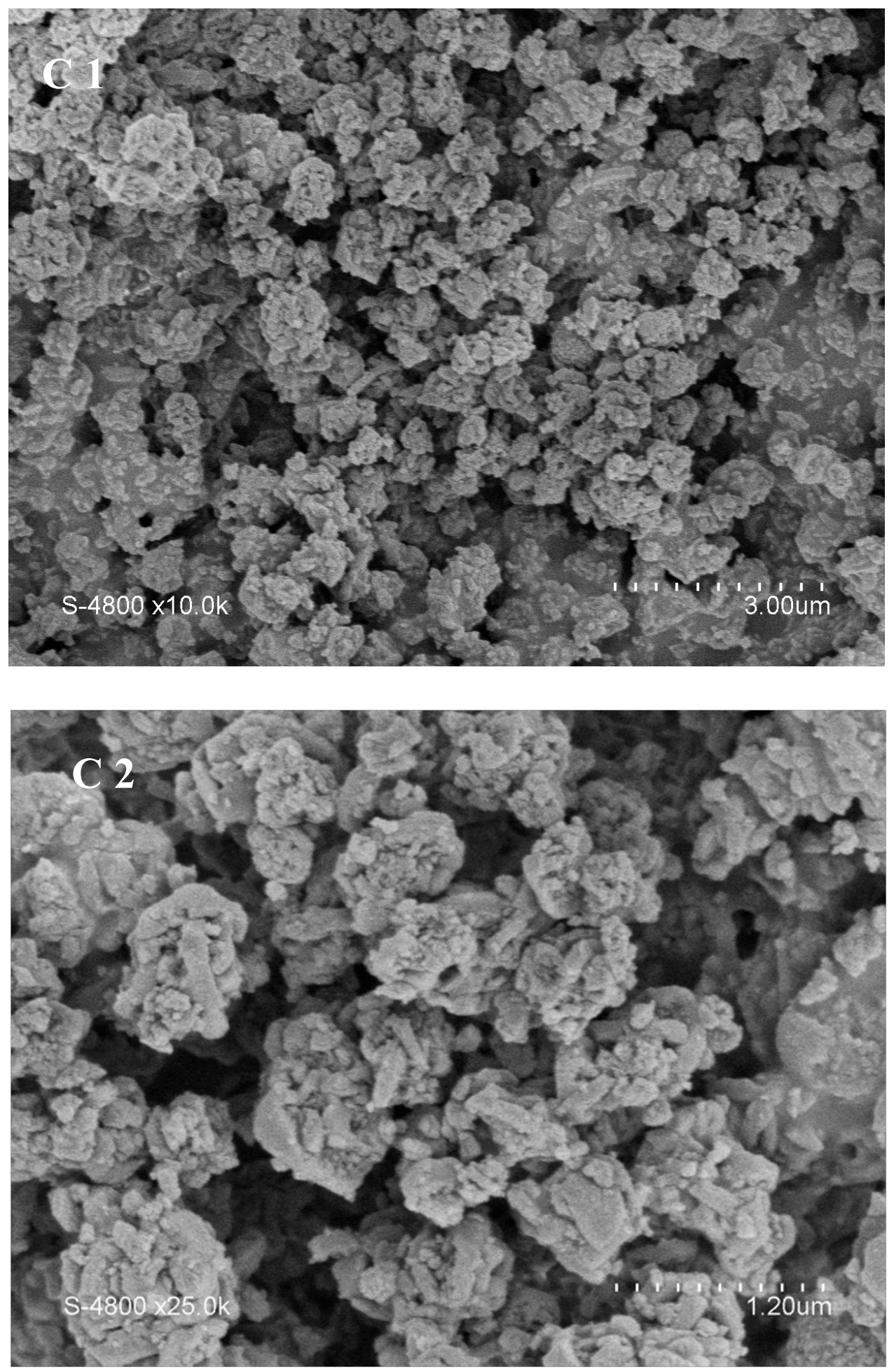
Figure 2 : SEM of (A1, A2) Na-F, (B1, B2) Ce (5)-F, and (C1, C2) Ce (20)-F .

The FTIR spectrum of Na-F zeolite was reported in Erreur ! Nous n'avons pas trouvé la source du renvoi. We found at $560 \mathrm{~cm}^{-1}$ the characteristic band related to the double six ring (D6R) in the faujasite zeolites[28]. The bands at $666 \mathrm{~cm}^{-1}$ and $957 \mathrm{~cm}^{-1}$ can be attributed to $\mathrm{TO}_{4}$ symmetric and asymmetric stretching vibration modes of $\mathrm{Si}-\mathrm{O}$, respectively. The peak at $447 \mathrm{~cm}^{-1}$ was attributed to T-O bending mode. The peak at $745 \mathrm{~cm}^{-1}$ is characteristic for symmetric stretching vibrations of external linkages[29]. The peak at $1646 \mathrm{~cm}^{-1}$ can be assigned to the bending mode of physically adsorbed water. According to Flanigen et al.[30], the T-O band near $455 \mathrm{~cm}^{-1}$ for the zeolite FAU type $\mathrm{Y}$ contains a high-frequency shoulder which is not present in zeolite FAU type X. Also, the $406 \mathrm{~cm}^{-1}$ pore opening band present in $\mathrm{X}$ zeolite is not found in Y zeolite.

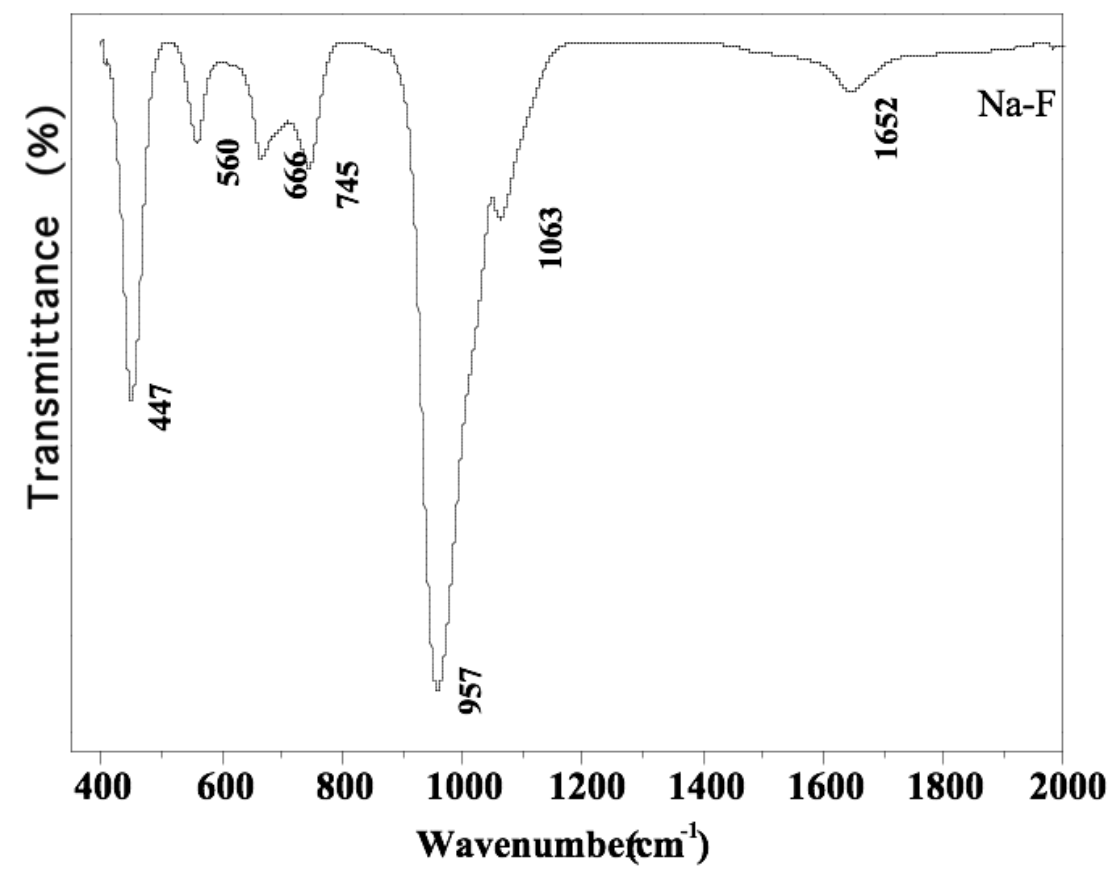


Figure 3 : FTIR spectrum of Na-F zeolite.

\subsection{Characterisationof the prepared catalysts}

Figure 4 showed the XRD patterns of the carrier Na-F and the Ce-exchanged catalysts $\mathrm{Ce}(5)-$ $\mathrm{F}, \mathrm{Ce}(10)-\mathrm{F}, \mathrm{Ce}(20)-\mathrm{F}$ and $\mathrm{Ce}(20)-\mathrm{F}_{\mathrm{C}}$. The XRD catalyst profiles demonstrate only peaks relative to the zeolite FAU without any supplementary peaks of cerium oxide or other $\mathrm{Ce}$ based phases. Thus, one can conclude that the cerium cations are not agglomerated and well dispersed into the zeolite porosity $[30,31]$. In general, with calcination at high temperature $\left(>300{ }^{\circ} \mathrm{C}\right)$, cerium ions located in the supercages starts to migrate to the sodalite cage and are

stabilized by the framework oxygens [33]. All catalysts have a light yellow color, this observation indicates the presence of cerium tetravalent[34].

On the other hand, the crystallinity of the catalysts decreased as the percentage of cerium increased. This feature can be explained by the removal of $\mathrm{Al}$ atoms from the framework without the destruction of the structure [32] due to the siting of cerium in the sodalite cages. It indicated that cerium had a strong interaction with the matrix of the zeolite[35]. 


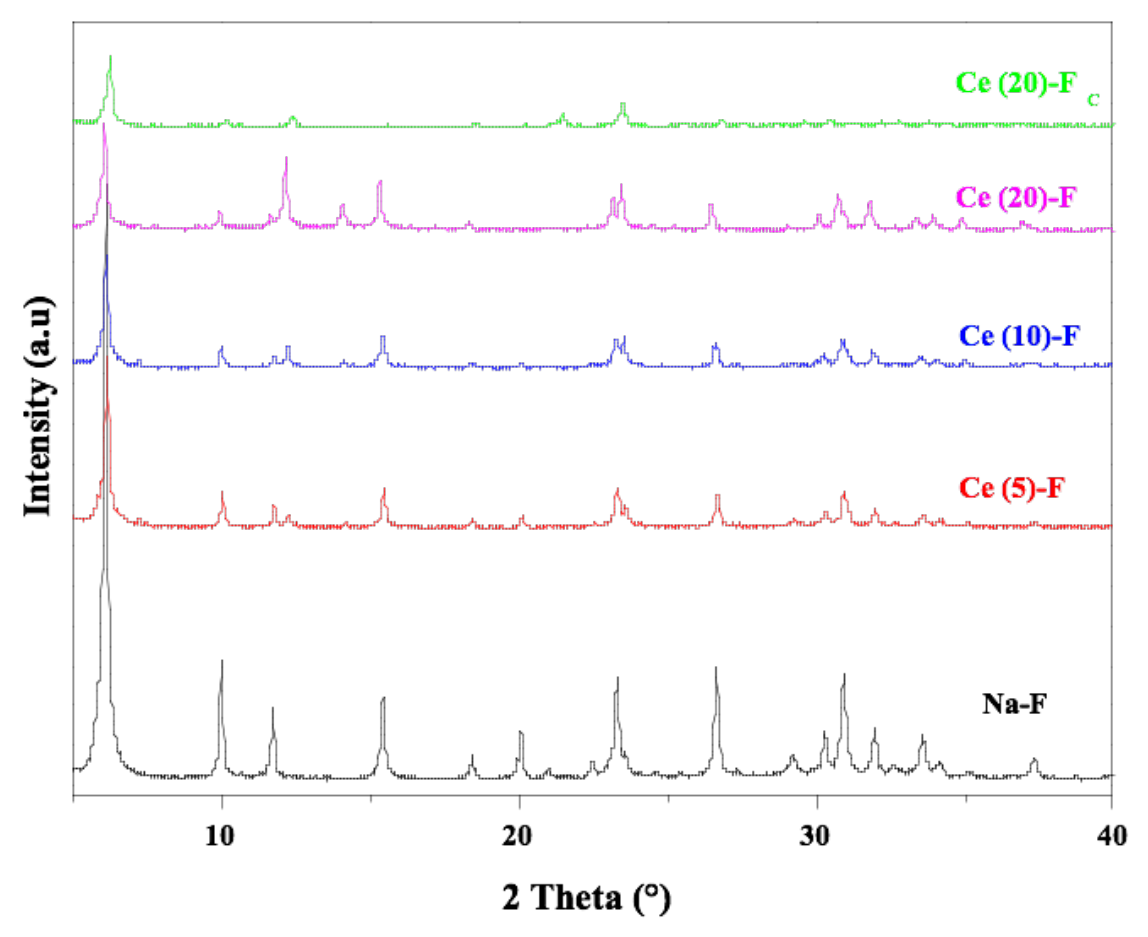

Figure 4 : XRD of Na-F, Ce (5)-F, Ce (10)-F, Ce (20)-F and $\mathrm{Ce}(20)-\mathrm{F}_{\mathrm{C}}$

The SEM micrographs of catalysts Ce (5)-F (B1, B2) and Ce $(20)-\mathrm{F}_{\mathrm{C}}(\mathrm{C} 1, \mathrm{C} 2)$ are reported inFigure 2. From this analysis we demonstrate that the two catalysts have the same morphology of the zeolite Na-F (Figure 2) with nanoscale crystals. Nevertheless, it was observed an agglomeration which is due to the interconnection of small particles, but the cerium particles is not observed in this magnification because they presented in a small amount.

Erreur! Nous n'avons pas trouvé la source du renvoi. presents the nitrogen adsorption-desorption isotherms of the samples Na-F, Ce (5)-F, Ce (10)-F, Ce (20)-F and Ce (20)-F. A typical type I adsorption isotherm is obtained in each case, indicating that the solids are microporous according to the classification ofIUPAC[36]. The presence of hysteresis loop from 0.66 to 0.98 arises indicated the presence of mesoporous from the packing of zeolite nanocrystals[37]. In Erreur! Nous n'avons pas trouvé la source du renvoi. were reported the BET surface area $\mathrm{S}_{\mathrm{BET}}$ external surface, micropore volume and micropore surface area of the samples Na- 
$\mathrm{F}$, Ce (5)-F, Ce (10)-F, Ce (20)-F and $\mathrm{Ce}(20)-\mathrm{F}_{\mathrm{C}}$. The BET total surface area $\left(\mathrm{S}_{\mathrm{BET}}\right)$ has changed under the condition of different Ce percentages from low to high with respect to microporous materials of Na-F zeolite itself, which possess rich specific surface area $\left(\mathrm{S}_{\mathrm{BET}}=\right.$ $749 \mathrm{~m}^{2} / \mathrm{g}$ ). The introduction of the rare earth cations causes a decrease in the micropore surface area and volume. It is attributed to the existence of the cerium cations or extraframework aluminum species in the cages or channels blocking the pore structure[38].

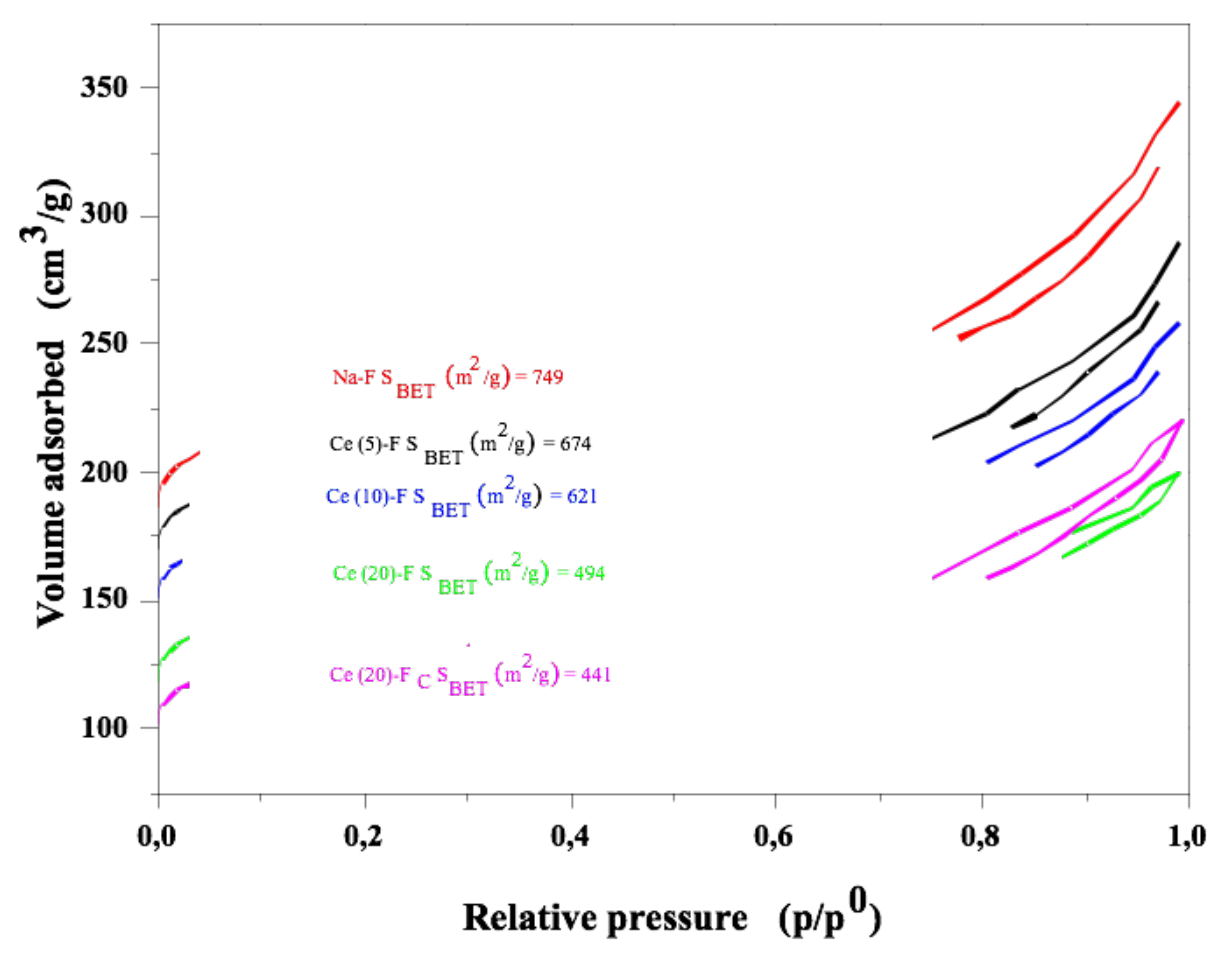

Figure 5 : BET of Na-F, Ce (5)-F, Ce (10)-F, Ce(20)-F and $\mathrm{Ce}(20)-\mathrm{F}_{\mathrm{C}}$.

Table 2 : BET surface area, external surface, micropore volume and micropore surface area of the samples Na-F, Ce (5)-F, Ce (10)-F, Ce (20)-F and Ce (20)- $\mathrm{F}_{\mathrm{C}}$.

\begin{tabular}{ccccc}
\hline Catalyts & $\mathbf{S}_{\text {BET }}\left(\mathbf{m}^{2} / \mathbf{g}\right)$ & $\mathbf{S}_{\text {external }}\left(\mathbf{m}^{2} / \mathbf{g}\right)$ & $\mathbf{V}_{\text {micropore }}\left(\mathbf{c m}^{3} / \mathbf{g}\right)$ & $\begin{array}{c}\text { Micropore } \\
\text { area }\left(\mathbf{m}^{2} / \mathbf{g}\right)\end{array}$ \\
\hline Na-F & 749 & 121 & 0.28 & 628 \\
\hline
\end{tabular}




\begin{tabular}{ccccc}
\hline $\mathbf{C e}(\mathbf{5})-\mathbf{F}$ & 674 & 81 & 0.27 & 592 \\
\hline $\mathbf{C e}(\mathbf{1 0})-\mathbf{F}$ & 621 & 82 & 0.24 & 538 \\
\hline $\mathbf{C e}(\mathbf{2 0})-\mathbf{F}$ & 494 & 75 & 0.19 & 418 \\
\hline $\mathbf{C e}(\mathbf{2 0})-\mathbf{F}_{\mathbf{C}}$ & 441 & 105 & 0.15 & 335 \\
\hline
\end{tabular}

The TGA/DTGA profiles of three samples were displayed in

Figure 6. The $\mathrm{Na}-\mathrm{F}, \mathrm{Ce}(20)-\mathrm{F}$ and $\mathrm{Ce}(20)-\mathrm{F}_{\mathrm{C}}$ show a mass loss at the range of temperature $\left(30-400^{\circ} \mathrm{C}\right)$ corresponding to water adsorbed on the surface and that present in the zeolite channels contributing to $21 \%, 25 \%$, and $18 \%$ of their total masses, respectively.

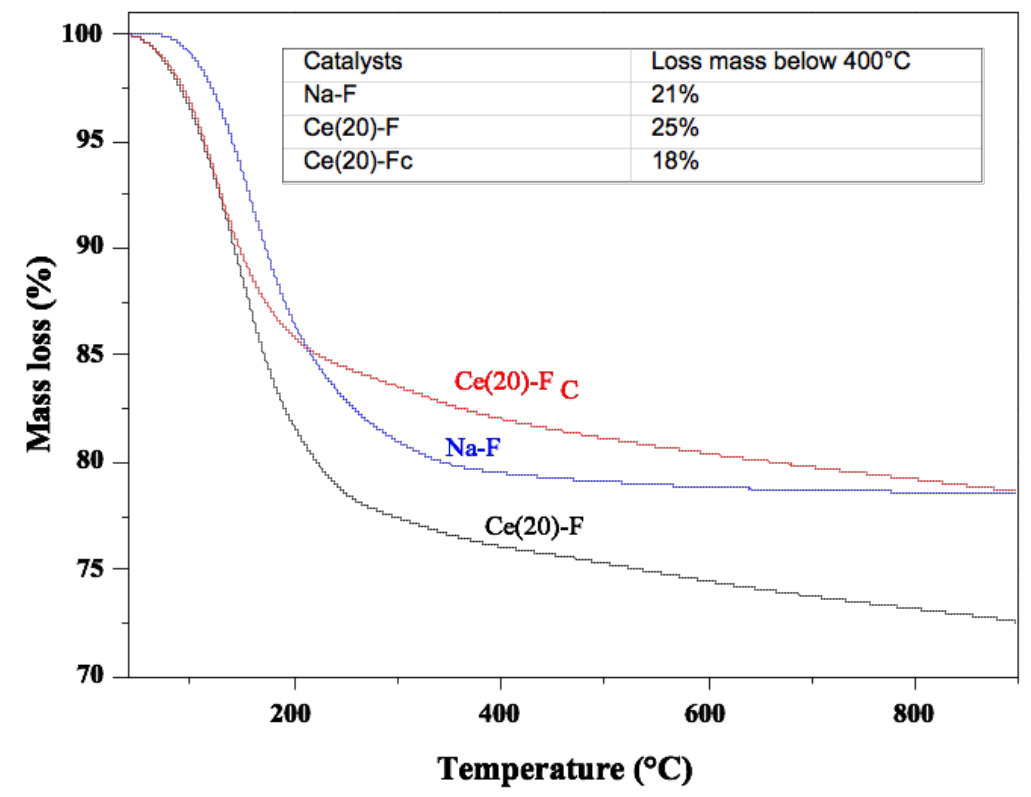




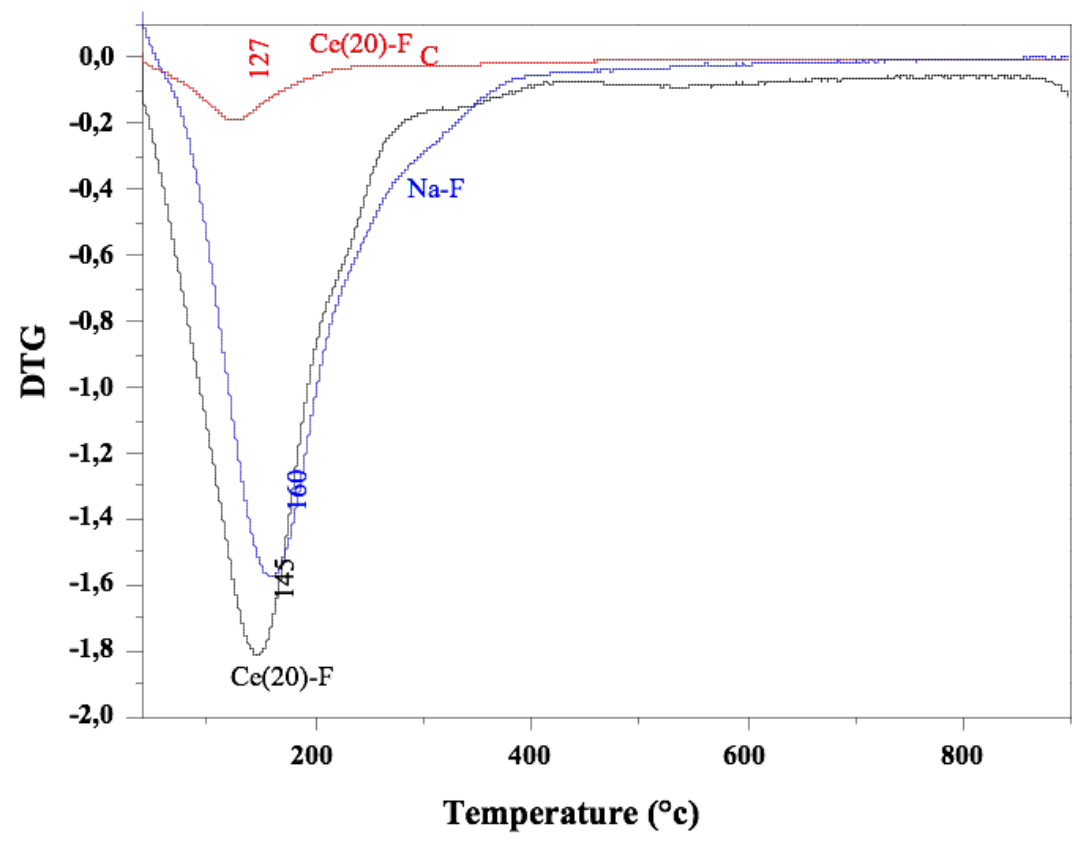

Figure 6 : TGA/DTGA of Na-F, Ce(20)-F and Ce(20)-F $\mathrm{F}_{\mathrm{C}}$

The diffuse reflectance UV-Vis spectroscopy is used to identify and characterize the metal ion coordination and its existence in metal position in the framework and/or extra-framework of zeolite. The diffuse reflectance UV-Vis spectra of catalysts Ce (5)-F, Ce (10)-F, Ce (20)-F, Ce (20) $-\mathrm{F}_{\mathrm{C}}$ and $\mathrm{CeO}_{2}$ are reported in

Figure 7.It showed single peak at $\sim 310 \mathrm{~nm}$ and its intensity increases with an increase in the Ce content of the samples. This band may be attributed to the charge transfer from $\mathrm{O} 2 \mathrm{p}$ to $\mathrm{Ce}$ 4f. The electronic transitions from oxygen to cerium need more energy for a hexa-coordinated than tetra-coordinated $\mathrm{Ce}^{4+}$. So, the band at $310 \mathrm{~nm}$ is due to the presence of one type of well-dispersed $\mathrm{Ce}^{4+}$ species probably in a tetra-coordinated environment[39]. For the pure ceria, the profile showed two peaks at 256 and $347 \mathrm{~nm}$. According to the literature [40] pure ceria presents three peaks at 255,285 and $340 \mathrm{~nm}$. The first peak corresponds to $\mathrm{O}^{2-}$ to $\mathrm{Ce}^{3+}$ 
charge transfer. Whereas, the other two peaks may be attributed to the $\mathrm{O}^{2-}$ to $\mathrm{Ce}^{4+}$ charge transfer $(285 \mathrm{~nm})$ and interband $(340 \mathrm{~nm})$ transition.

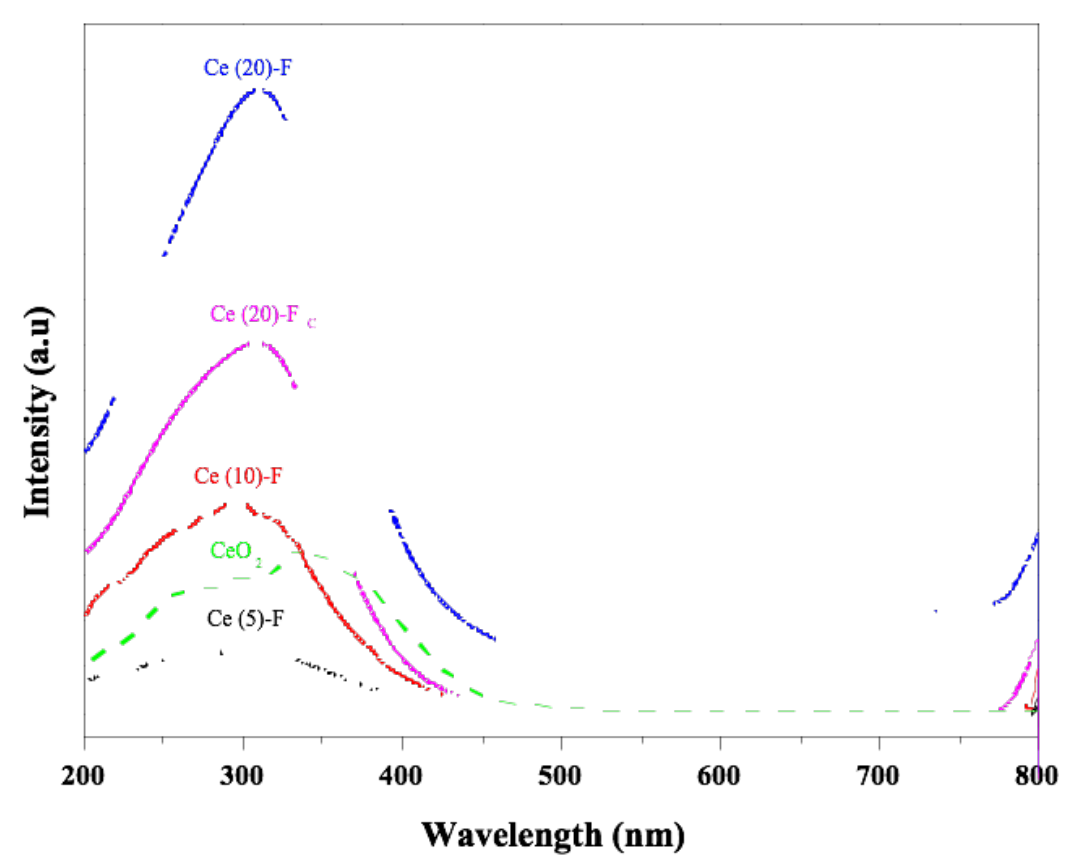

Figure 7 : UV-vis spectroscopy of $\mathrm{Ce}(5)-\mathrm{F}, \mathrm{Ce}(10)-\mathrm{F}, \mathrm{Ce}(20)-\mathrm{F}, \mathrm{Ce}(20)-\mathrm{F}_{\mathrm{C}}$ and $\mathrm{CeO}_{2}$.

The $\mathrm{H}_{2}$-TPR analysis was used to study the reducibility of Ce present in the catalysts. The reduction profiles of the different catalysts ( $\mathrm{Ce}(5)-\mathrm{F}, \mathrm{Ce}(10)-\mathrm{F}$ and $\left.\mathrm{Ce}(20)-\mathrm{F}_{\mathrm{C}}\right)$ and $\mathrm{CeO}_{2}$ (Sigma Aldrich 316970) are reported in

Figure 8. The profile of the pure $\mathrm{CeO}_{2}$ presents two reduction peaks. The first one at lower temperature $\left(520^{\circ} \mathrm{C}\right)$ can be related to the reduction of the surface capping oxygen $\mathrm{Ce}^{4+}-\mathrm{O}-$ $\mathrm{Ce}^{4+}$. The second peak at high temperature around $890^{\circ} \mathrm{C}$ correspond to the reduction of oxygen in the bulk (elimination of $\left.\mathrm{O}^{2-}\right)[41]$. For the three catalysts $\mathrm{Ce}(5)-\mathrm{F}, \mathrm{Ce}(10)-\mathrm{F}$ and $\mathrm{Ce}(20)-\mathrm{F}_{\mathrm{C}}$, the large peaks around 527,557 and $512^{\circ} \mathrm{C}$, respectively were attributed to the 
reduction of $\mathrm{Ce}^{4+}$ to $\mathrm{Ce}^{3+}$. It is noted that the $\mathrm{H}_{2}$ consumption increases with the increasing of the quantity of cerium in zeolite. For the catalyst $\mathrm{Ce}(20)-\mathrm{F}_{\mathrm{C}}$, the deconvolution of the reduction profile showed two peaks at 461 and $541^{\circ} \mathrm{C}$. The first one could be attributed to the reduction of $\mathrm{Ce}^{4+}$ ions present in the supercages whereas the second one to the reduction of $\mathrm{Ce}^{4+}$ ions in the sodalites presen zeolite and the second one can be related to isolated cerim species[42]. With the two steps preparation including the high temperature of calcinations, Ce ions may enter are in the $\mathrm{S}_{\mathrm{I}}$ sites coordinated with three oxygen atoms of the zeolitic framework and have substituted the sodium in the sodalite cages. $\mathrm{Ce}^{4+}$ ions located in the sodalites are more difficult to be

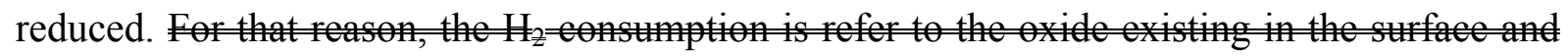
in the supelite [43].

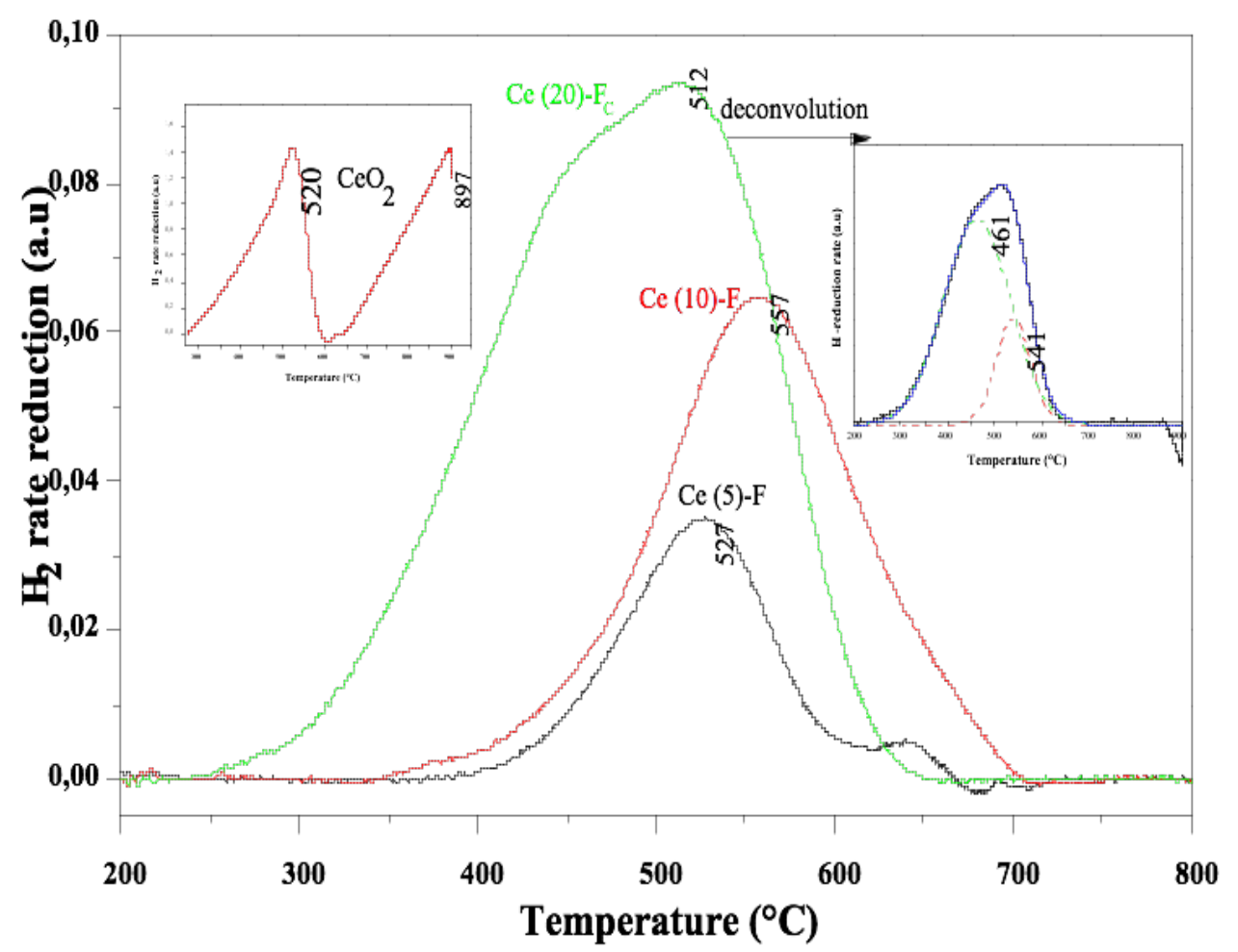

Figure $8: \mathrm{H}_{2}-\mathrm{TPR}$ of $\mathrm{Ce}(5)-\mathrm{F}, \mathrm{Ce}(10)-\mathrm{F}$ and $\mathrm{Ce}(20)-\mathrm{F}_{\mathrm{C}}$ and pure $\mathrm{CeO}_{2}$. 


\subsection{Selective catalytic reduction of $\mathrm{NO}$ by $\mathrm{NH}_{3}$}

\subsubsection{NO conversion of fresh catalysts}

The NO conversion to $\mathrm{N}_{2}$ of Fresh catalysts Ce (5)-F, Ce (10)-F, Ce (20)-F, Ce (20)-F and Na-F are shown in

Figure 9. At first, it should be mentioned that catalysts do not produce $\mathrm{N}_{2} \mathrm{O}$ over the whole range of studied temperatures. The support Na-F presents a poor NO conversion about $12 \%$ at $550{ }^{\circ} \mathrm{C}$. The introduction of cerium to $\mathrm{Na}-\mathrm{F}$ zeolite produces marked changes in the catalytic behavior. As seen for the less exchanged catalyst $\mathrm{Ce}(5)-\mathrm{F}$, the NO conversion increased from $2 \%$ at $250^{\circ} \mathrm{C}$ to $55 \%$ at $500^{\circ} \mathrm{C}$. The further increase of cerium content in the catalysts; $\mathrm{Ce}(10)-$ $\mathrm{F}$ and Ce (20)-F enhanced the NO conversion. The catalyst Ce(10)-F showed an increase of NO conversion from $6 \%$ at 250 to $88 \%$ at $500^{\circ} \mathrm{C}$ and then remained constant $(88 \%$ of $\mathrm{NO}$ conversion) above this temperature. For the catalyst $\mathrm{Ce}(20)-\mathrm{F}$, NO conversion is already of $40 \%$ at $200^{\circ} \mathrm{C}$ and then, it increased gradually with the increase of temperature and reached $100 \%$ of $\mathrm{NO}$ conversion at $400^{\circ} \mathrm{C}$. Compared to $\mathrm{Ce}(20)-\mathrm{F}$ catalyst, $\mathrm{Ce}(20)-\mathrm{F}_{\mathrm{C}}$ was less active at temperatures below $400{ }^{\circ} \mathrm{C}$ but $\mathrm{NO}$ conversion reached $100 \%$ at $500{ }^{\circ} \mathrm{C}$. On the other hand, the light-off temperature (T50), the maximum NO conversions and the related temperatures of $\mathrm{Ce}(5)-\mathrm{F}, \mathrm{Ce}(10)-\mathrm{F}$ and catalysts were reported in Table 3. It can be seen that $\mathrm{Ce}(20)-\mathrm{F}$ catalyst is more active and has the lowest light-off temperature than the other catalysts. 
Furthermore, with the increase of cerium content for $\mathrm{Ce}(\mathrm{x})-\mathrm{F}$ catalysts there was a decrease of the T50 and an increase of the NO conversions.

As said before, withthe increase of cerium content there was an increase of NO conversion in the whole temperature range. Literature reported that the high activity cerium catalysts in the $\mathrm{NH}_{3}-\mathrm{SCR}[44]$ is due to the redox property of $\mathrm{Ce}^{4+} / \mathrm{Ce}^{3+}$ couple. Indeed, in the presence of oxygen, $\mathrm{Ce}^{3+}$ oxidized toCe ${ }^{4+}$ which oxidizesNO to $\mathrm{NO}_{2}$, in low temperature region, which is among the key steps in theNH $\mathrm{N}_{3}-\mathrm{SCR}$. The cerium have a redox property like the others transition metal, but the cerium have orbital $\mathrm{f}$ which make the distribution of catalytic sites, like oxygen vacancies, especially in the case of surface redox reactions[44], e.g. bonding with molecules like nitric oxides[45].Also the orbital $4 \mathrm{f}$ of $\mathrm{Ce}^{4+}$ cation, in the surface, has the capacity to store and release reversibly or selectively electrons, so this property can have an impact in the stabilization of adsorbed reactants and induced their reactions. So the presence of sufficient oxygen vacancies on the surface is the key to initiate the co-adsorption of $\mathrm{NO}$ and the later reaction for the formation of $\mathrm{N}_{2}$ [44].

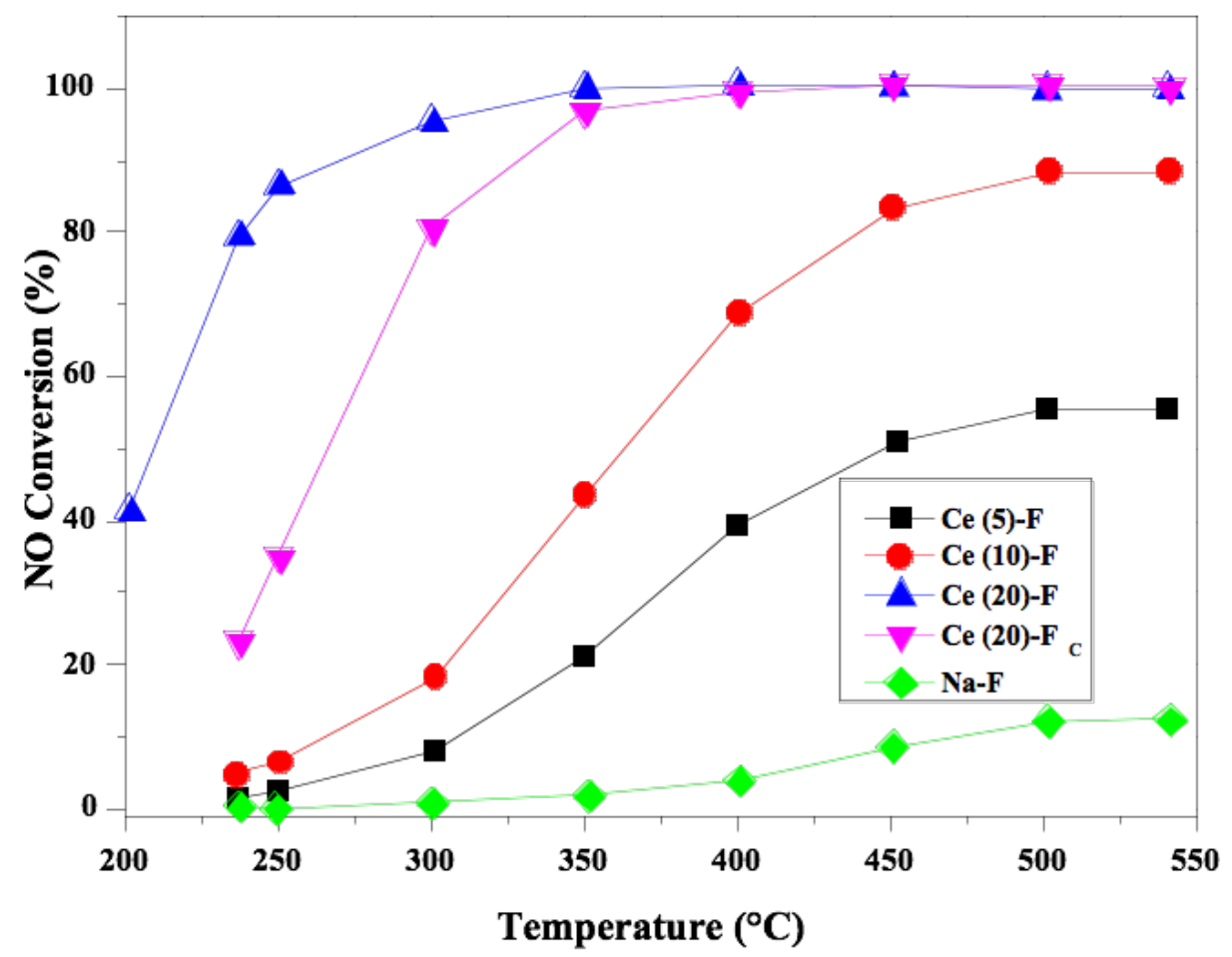


Figure 9 :The NO conversion of Fresh catalysts Ce (5)-F, Ce (10)-F,Ce (20)-F, Ce (20)$\mathrm{F}_{\mathrm{C}}$ and Na-F support.

Table 3: The light of temperatures, the maximum NO conversions and the related temperatures of prepared catalysts.

\begin{tabular}{cccc}
\hline Catalysts & $\mathbf{T}_{\mathbf{5 0}}\left({ }^{\circ} \mathbf{C}\right)$ & NO Con (\%) & $\mathbf{T ~ m a x ~}\left({ }^{\circ} \mathbf{C}\right)$ \\
\hline $\mathrm{Ce}(5)-\mathrm{F}$ & 452 & 55 & 500 \\
$\mathrm{Ce}(10)-\mathrm{F}$ & 365 & 88 & 500 \\
$\mathrm{Ce}(20)-\mathrm{F}$ & 210 & 100 & 350 \\
$\mathrm{Ce}\left(20-\mathrm{F}_{\mathrm{C}}\right.$ & 267 & 100 & 400 \\
\hline
\end{tabular}

\subsubsection{Hydrothermal stability}

An hydrothermal treatment at high temperature is usually used for simulating the ageing of the $\mathrm{NH}_{3}$-SCR catalysts for the automotive applications. To study the effect of hydrothermal treatment, two sets of experiments were performed by aging all catalysts at 700 and $800^{\circ} \mathrm{C}$ for 4 hours in the presence of $10 \%$ of water vapor.Figures 10and 11 reported the NO conversions of the hydrotreated catalysts $\mathrm{Ce}(\mathrm{x})-\mathrm{F}$ at 700 and $800^{\circ} \mathrm{C}$ for 4 hours in the presence of $10 \%$ of water vapor, respectively. After hydrothermal treatment at $700{ }^{\circ} \mathrm{C}($ 
Figure 10 : Hydrothermal treatment of $\mathrm{Ce}(5)-\mathrm{F}, \mathrm{Ce}(10)-\mathrm{F}, \mathrm{Ce}(20)-\mathrm{F}$ and $\mathrm{Ce}(20)-\mathrm{FC}$ at $7^{\circ 0}{ }^{\circ} \mathrm{C}$ for 4 hours.

), all aged catalysts show different degrees of activity loss at high temperatures compared with fresh catalysts. However, for the catalyst with highest cerium content $\mathrm{Ce}(20)-\mathrm{F}_{\mathrm{C}} \mathrm{ht} 700$ shows a slight degradation of NO conversion throughout the temperature range. . In table 4, we reported the NO conversions of fresh and aged catalysts at $500^{\circ} \mathrm{C}$. From these results, it is noted that when the percentage of cerium increases the catalyst remains stable after hydrothermal treatment and has a good NO conversion. Indeed, the Ce(20)-Fht700 catalyst

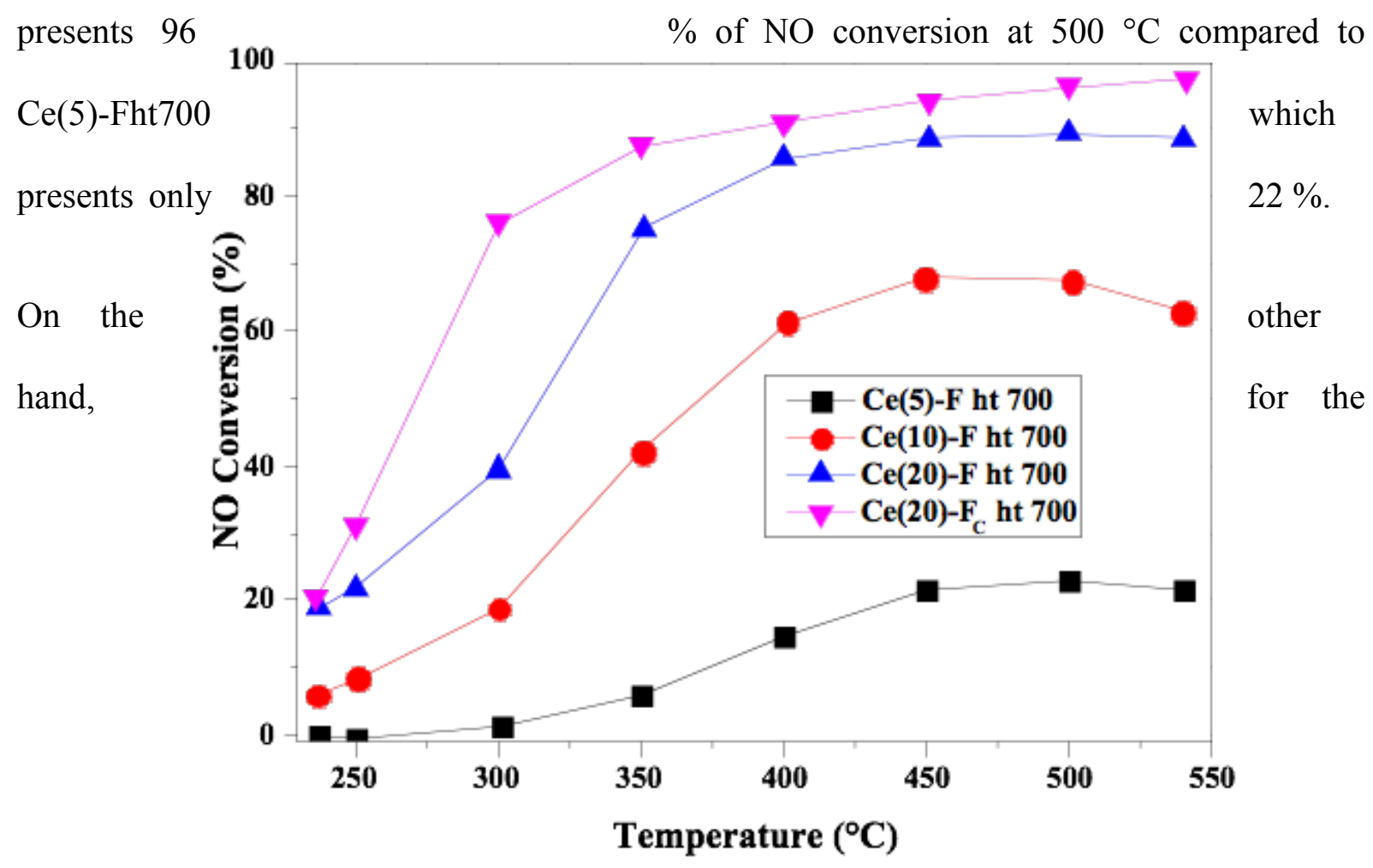


hydrotreated catalysts at $800^{\circ} \mathrm{C}$, one can observe that the increase of the aging temperature has a remarkable influence on the catalytic performance. For the two catalysts $\mathrm{Ce}(5)-\mathrm{Fht} 800$ and $\mathrm{Ce}(10)$-Fht800,NO conversions drastically decreased to16 \% and 13\%, respectively. Furthermore, the catalyst $\mathrm{Ce}(20)$-Fht 800 presents only $81 \%$ of conversion at $500^{\circ} \mathrm{C}$. But for the $\mathrm{Ce}(20)-\mathrm{F}_{\mathrm{C}}$ ht 800 the conversion remains stable $\left(96 \%\right.$ of $\mathrm{NO}$ conversion) at $500^{\circ} \mathrm{C}$. The above results indicate that $\mathrm{Ce}(20)-\mathrm{F}_{\mathrm{C}}$ ht800 is more stable than other catalysts during the hydrothermal treatment. Because of its hydrothermal stability the catalyst $\mathrm{Ce}(20)-\mathrm{F}_{\mathrm{C}} \mathrm{ht} 800$ was tested after undergoing higher hydrothermal treatment temperature, 850 and $900^{\circ} \mathrm{C}$, for 4 hours.

Figure 10: Hydrothermal treatment of $\mathrm{Ce}(5)-\mathrm{F}, \mathrm{Ce}(10)-\mathrm{F}, \mathrm{Ce}(20)-\mathrm{F}$ and $\mathrm{Ce}(20)-\mathrm{F}_{\mathrm{C}}$ at $700^{\circ} \mathrm{C}$ for 4 hours. 


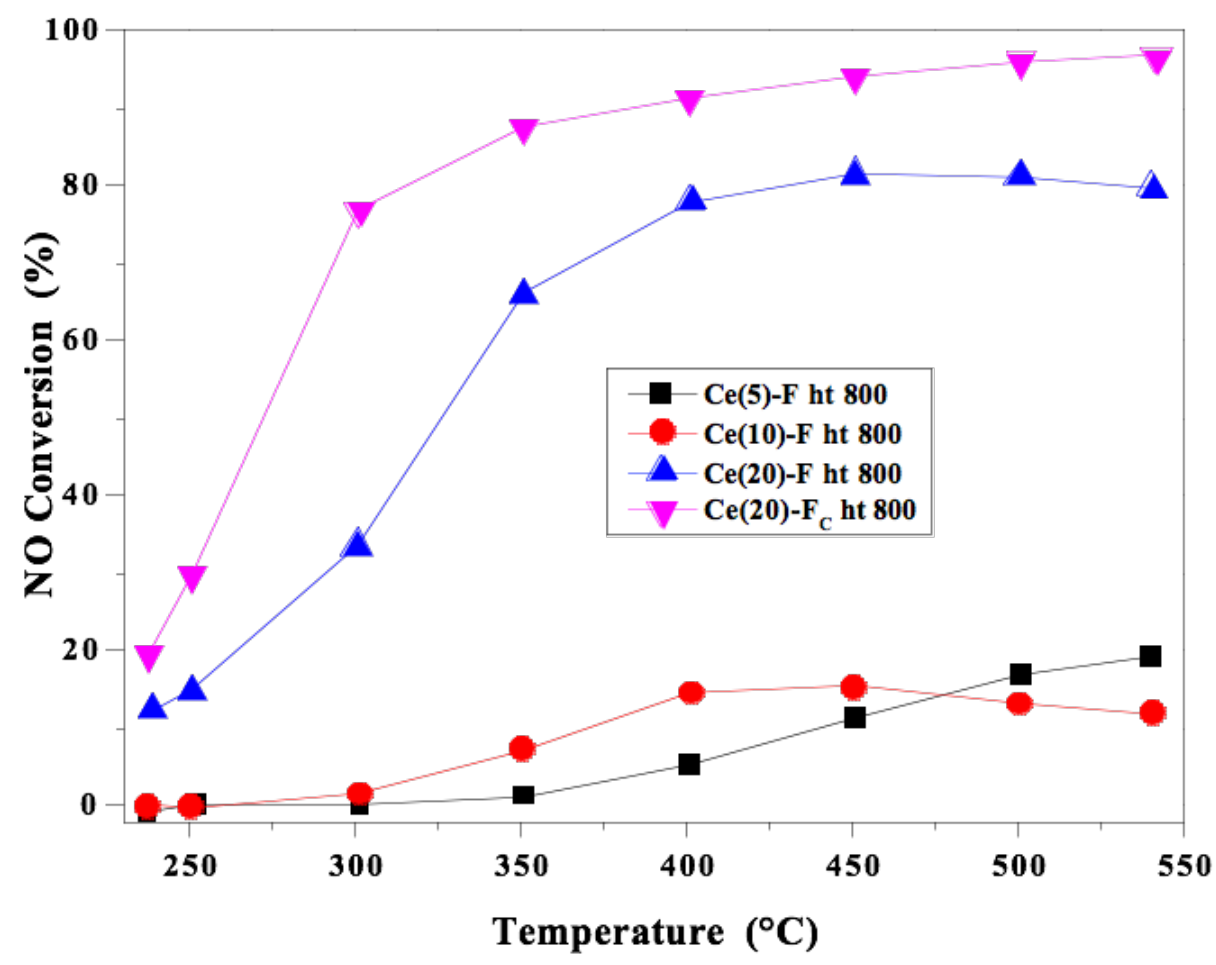

Figure 11 :Hydrothermal treatment of $\mathrm{Ce}(5)-\mathrm{F}, \mathrm{Ce}(10)-\mathrm{F}, \mathrm{Ce}(20)-\mathrm{F}$ and $\mathrm{Ce}(20)-\mathrm{F}_{\mathrm{C}}$ at $800^{\circ} \mathrm{C}$ for 4hours.

Table 4 : NO conversionsat $500^{\circ} \mathrm{C}$ of fresh and aged catalysts at $700{ }^{\circ} \mathrm{C}$ and $800{ }^{\circ} \mathrm{C}$.

\begin{tabular}{cccc}
\hline Catalysts & $\begin{array}{c}\text { NO Conv. Fresh } \\
\text { catalysts (\%) }\end{array}$ & $\begin{array}{c}\text { NO Conv after H.T } \\
\mathbf{7 0 0}^{\circ} \mathbf{C}(\mathbf{\%})\end{array}$ & $\begin{array}{c}\text { NO Conv.After H.T } \\
\mathbf{8 0 0}^{\circ} \mathbf{C}(\%)\end{array}$ \\
\hline $\mathbf{C e}(\mathbf{5})-\mathrm{F}$ & 55 & 22 & 16 \\
\hline $\mathbf{C e}(\mathbf{1 0})-\mathbf{F}$ & 88 & 67 & 13 \\
\hline $\mathbf{C e}(\mathbf{2 0})-\mathbf{F}$ & 100 & 89 & 86 \\
\hline $\mathbf{C e}(\mathbf{2 0})-\mathbf{F}_{\mathbf{C}}$ & 100 & 96 & 96 \\
\hline
\end{tabular}


Figure 12 presents the NO conversion of $\mathrm{Ce}(20)-\mathrm{F}_{\mathrm{C}}$ catalyst before and after hydrothermal treatment for 4 hours at $700,800,850$ and $900^{\circ} \mathrm{C}$. It is noted that the $\mathrm{NO}$ conversions decreased slightly from $100 \%$ for the fresh catalyst to about $95 \%$ for the catalysts: Ce (20)$\mathrm{F}_{\mathrm{C}} \mathrm{ht} 700, \mathrm{Ce}(20)-\mathrm{F}_{\mathrm{C}} \mathrm{ht} 800$ and $\mathrm{Ce}(20)-\mathrm{F}_{\mathrm{C}}$ ht 850 . Nevertheless, after hydrothermal treatment at $900^{\circ} \mathrm{C}\left(\mathrm{Ce}(20)-\mathrm{F}_{\mathrm{C}}\right.$ ht 900$)$ the catalytic activity was decreased to $12 \%$. This reduction in the conversion is due to the destruction of the catalyst structure and the formation of cerium oxide at $28^{\circ}$ and $47^{\circ}$ as shown by the XRD (

\section{Figure 13).}

The slight decrease of $\mathrm{NO}$ conversions for the catalysts hydrotreated at $700{ }^{\circ} \mathrm{C}, 800{ }^{\circ} \mathrm{C}$ and $850{ }^{\circ} \mathrm{C}$ can be related to the presence of cerium cations into the sodalite cages of the zeolite Na-F. Actually, during the preparation of the catalyst $\mathrm{Ce}(20)-\mathrm{F}_{\mathrm{C}}$, the latter was calcined at higher temperature $\left(750^{\circ} \mathrm{C}\right)$ compared to the other catalysts $\left(450{ }^{\circ} \mathrm{C}\right)$. The use of this higher calcination temperature permits to the cerium cations to migrate from the supercage to the sodalite cage and to form bridges with the oxygen framework which stabilize the zeolites tructure[46, 47]. Y. Shu et al. [46] reported that the hydrothermal treatment of zeolite catalysts at high temperatures $\left(500-800^{\circ} \mathrm{C}\right)$, provokes the dealumination of the framework especially for those having low $\mathrm{Si} / \mathrm{Al}$ ratio. So, the aluminum atoms migrate from their 
positions and settle down in zeolite channels and cages. To moderate the deactivation of the zeolite catalysts rare earth cations like cerium was added to the formulation. The addition of cerium prevented the framework dealumination, and preserved the acid sites, which greatly ameliorated the hydrothermal stability.
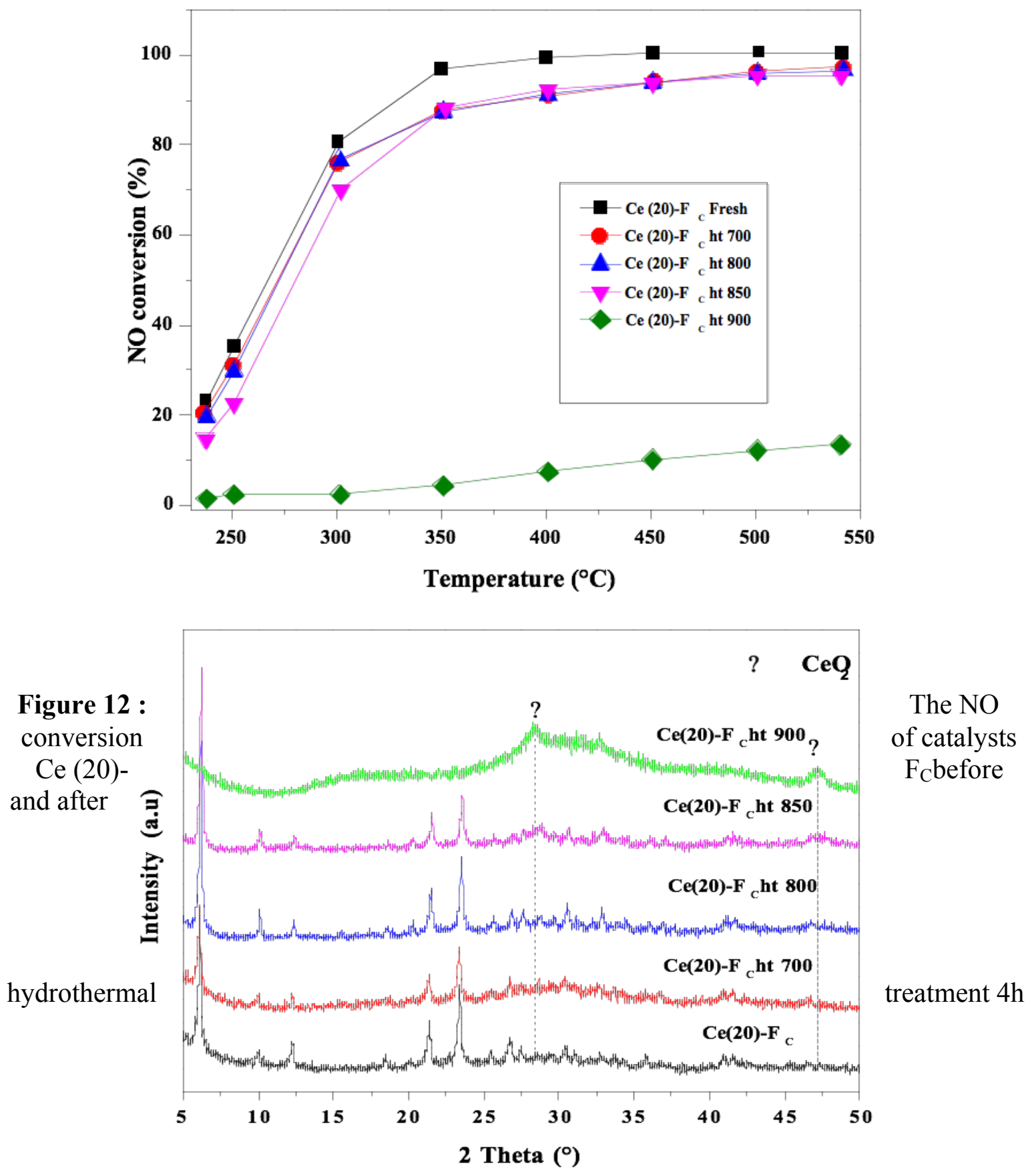
at $700,800,850$ and $900^{\circ} \mathrm{C}$.

Figure 13 : XRD of catalyst $\mathrm{Ce}(20)-\mathrm{F}_{\mathrm{C}}$ before and after hydrothermal treatment $4 \mathrm{~h}$ at $700,800,850$ and $900^{\circ} \mathrm{C}$.

\section{Conclusion}

In this study, FAU zeolite has been prepared using cheap starting materials; aluminum scrap and industrial sodium metasilicate with hydrogel molar composition $5.19 \mathbf{N a}_{2} \mathbf{O}: \mathbf{A l}_{2} \mathbf{O}_{3}: \mathbf{2 . 9}$ $\mathrm{SiO}_{2}: \mathbf{1 8 2 . 7 6} \mathrm{H}_{2} \mathrm{O}$. The obtained zeolite after hydrothermal synthesis at $80{ }^{\circ} \mathrm{C}$ for $24 \mathrm{~h}$, has been used as carrier to prepare cerium exchanged catalysts with different cerium content.The NO conversion increased with increasing the percentage of cerium in the framework of zeolite. The best catalytic activities is concerned to the catalysts $\mathrm{Ce}(20)-\mathrm{F}$ and $\mathrm{Ce}(20)-\mathrm{F}_{\mathrm{C}}$ catalyst. It should be underlined that, after hydrothermal treatment of the catalysts, $\mathrm{Ce}(20)-\mathrm{F}_{\mathrm{C}}$ at $850^{\circ} \mathrm{C}$ for 4 hours, $\mathrm{NO}$ conversion remains stable whereas for $\mathrm{Ce}(20)-\mathrm{F}$ prepared by a classic way, a noticeable loss of activity is already observed after hydrothermal treatment at $800^{\circ} \mathrm{C}$. The two steps procedure, allowing the siting of Ce ions into the sodalite cages of the 
faujasite greatly improves the hydrothermal stability of the catalysts. Contrarly to copper faujasite, Ce-FAU catalysts shows hydrothermal stability comparable to other small pore zeolithe structures. The increase of the hydrothermal treatment temperature to $900^{\circ} \mathrm{C}$ leads to a drastic decrease of NO conversion to $12 \%$. This behavior can be related to the destruction of structure of zeolite and the appearance of $\mathrm{CeO}_{2}$ peaks as shown by XRD technique and is generally observed for the other zeolite structures.

\section{References}

[1] S. Brandenberger, O. Kröcher, A. Tissler, and R. Althoff, The state of the art in selective catalytic reduction of NOxby ammonia using metal-exchanged zeolite catalysts, vol. 50, no. 4. 2008.

[2] U.S. EPA, "Overview of the human health and environmental effects of power generation: focus on sulfur dioxide, nitrogen oxides, and mercury," Clear Ski. Initiat., 2002.

[3] F. Gao et al., A Review on Selective Catalytic Reduction of NOx by NH3 over Mn- 
Based Catalysts at Low Temperatures: Catalysts, Mechanisms, Kinetics and DFT Calculations, vol. 7, no. 7. 2017.

[4] D. E. L. Ille, R. E. Catalytique, S. Des, O. D. Azote, L. H. Ou, and L. E. Methane, "L'u s t $1,, 2004$.

[5] S. Roy, M. S. Hegde, and G. Madras, "Catalysis for NOxabatement," Appl. Energy, vol. 86, no. 11, pp. 2283-2297, 2009.

[6] M. König, K. Eisinger, I. Hartmann, and M. Müller, "Combined removal of particulate matter and nitrogen oxides from the exhaust gas of small-scale biomass combustion," no. X, 2018.

[7] M. Moreno-González, A. E. Palomares, M. Chiesa, M. Boronat, E. Giamello, and T. Blasco, "Evidence of a $\mathrm{Cu} 2+-A 1 k a n e$ Interaction in $\mathrm{Cu}$-Zeolite Catalysts Crucial for the Selective Catalytic Reduction of NOx with Hydrocarbons," ACS Catal., vol. 7, no. 5, pp. 3501-3509, May 2017.

[8] X. You, Z. Sheng, D. Yu, L. Yang, X. Xiao, and S. Wang, "Influence of Mn/Ce ratio on the physicochemical properties and catalytic performance of graphene supported MnOx-CeO2 oxides for NH3-SCR at low temperature," Appl. Surf. Sci., vol. 423, pp. 845-854, 2017.

[9] X. Yao et al., "Selective catalytic reduction of NOx by $\mathrm{NH} 3$ over $\mathrm{CeO} 2$ supported on TiO2: Comparison of anatase, brookite, and rutile," Appl. Catal. B Environ., vol. 208, pp. 82-93, 2017.

[10] L. Li et al., "Ultra-low loading of copper modified TiO2/CeO2 catalysts for lowtemperature selective catalytic reduction of NO by NH3," Appl. Catal. B Environ., vol. 207, pp. 366-375, 2017.

[11] J. Grzybek, B. Gil, W. J. Roth, M. Skoczek, A. Kowalczyk, and L. Chmielarz, "Characterization of $\mathrm{Co}$ and Fe-MCM-56 catalysts for NH3-SCR and N2O decomposition: An in situ FTIR study," Spectrochim. Acta Part A Mol. Biomol. Spectrosc., vol. 196, pp. 281-288, 2018.

[12] M. P. Ruggeri, I. Nova, E. Tronconi, V. Schmeißer, and M. Weibel, "Modelling the Hydrothermal Ageing of a Fe-Zeo- lite Catalyst for Automotive NH 3 -SCR Applications," no. 0, pp. 1-14, 2018.

[13] H. Wang, R. Xu, Y. Jin, and R. Zhang, "Zeolite structure effects on $\mathrm{Cu}$ active center, SCR performance and stability of Cu-zeolite catalysts," Catal. Today, 2018.

[14] L. Zhao et al., "Simultaneous removal of elemental mercury and NO in simulated flue gas over V2O5/ZrO2-CeO2 catalyst," Appl. Catal. B Environ., vol. 198, pp. 420-430, 2016.

[15] X. Wang, Z. Chen, Y. Wang, and R. Wang, "Rare- Earth- Doped Pt/Ba/Ce0. 6Zr0. 4O2- A12O3 for NOx Storage and Reduction: The Effect of Rare- Earth Doping on Efficiency and Stability," ChemCatChem, vol. 6, no. 1, pp. 237-244, 2014.

[16] R. Guo, Y. Zhou, W. Pan, J. Hong, and W. Zhen, "Journal of Industrial and Engineering Chemistry Effect of preparation methods on the performance of $\mathrm{CeO} 2 /$ $\mathrm{Al} 2 \mathrm{O} 3$ catalysts for selective catalytic reduction of $\mathrm{NO}$ with $\mathrm{NH} 3$," J. Ind. Eng. 
Chem., vol. 19, no. 6, pp. 2022-2025, 2013.

[17] X. Yao, L. Chen, J. Cao, F. Yang, W. Tan, and L. Dong, "Morphology and CrystalPlane Effects of $\mathrm{CeO} 2$ on $\mathrm{TiO} 2 / \mathrm{CeO} 2$ Catalysts during NH3-SCR Reaction," Ind. Eng. Chem. Res., Aug. 2018.

[18] Q. Jin, Y. Shen, and S. Zhu, "Praseodymium Oxide Modified CeO 2 / Al 2 O 3 Catalyst for Selective Catalytic Reduction of NO by NH 3," pp. 1283-1290, 2016.

[19] A. K. Ingole, D. Dixit, and S. V Dingare, "A review on Selective Catalytic Reduction technique for diesel engine exhaust after treatment," vol. 7, no. 7, pp. 206-210, 2017.

[20] T. Boningari et al., "Influence of elevated surface texture hydrated titania on Ce-doped $\mathrm{Mn} / \mathrm{TiO} 2$ catalysts for the low-temperature SCR of NO $\mathrm{x}$ under oxygen-rich conditions," J. Catal., vol. 325, pp. 145-155, 2015.

[21] A. Manuscript, "Catalysis Science \& Technology,” 2015.

[22] X. Wang et al., "E ff ect of Ceria Precursor on the Physicochemical and Catalytic Properties of $\mathrm{Mn}-\mathrm{W} / \mathrm{CeO} 2$ Nanocatalysts for NH 3 SCR at Low Temperature," 2017.

[23] Q. Zhang et al., "Applied Surface Science In situ DRIFTS investigation of NH 3 -SCR reaction over CeO 2 / zirconium phosphate catalyst," Appl. Surf. Sci., vol. 435, pp. 1037-1045, 2018.

[24] G. Carja, Y. Kameshima, K. Okada, and C. D. Madhusoodana, "Mn-Ce/ZSM5 as a new superior catalyst for NO reduction with NH3," Appl. Catal. B Environ., vol. 73, no. 1-2, pp. 60-64, 2007.

[25] G. Qi and R. T. Yang, "Performance and kinetics study for low-temperature SCR of NO with NH3 over MnOx-CeO2 catalyst," J. Catal., vol. 217, no. 2, pp. 434-441, 2003.

[26] Z. Wu, R. Jin, H. Wang, and Y. Liu, "Effect of ceria doping on SO2 resistance of $\mathrm{Mn} / \mathrm{TiO} 2$ for selective catalytic reduction of $\mathrm{NO}$ with $\mathrm{NH} 3$ at low temperature," Catal. Commun., vol. 10, no. 6, pp. 935-939, 2009.

[27] M. M. J. Treacy and J. B. Higgins, Collection of simulated XRD powder patterns for zeolites fifth (5th) revised edition. Elsevier, 2007.

[28] B.-Z. Zhan et al., "Control of particle size and surface properties of crystals of $\mathrm{NaX}$ zeolite," Chem. Mater., vol. 14, no. 9, pp. 3636-3642, 2002.

[29] Y. Zhan, X. Li, Y. Zhang, L. Han, and Y. Chen, "Phase and morphology control of LTA/FAU zeolites by adding trace amounts of inorganic ions," Ceram. Int., vol. 39, no. 5, pp. 5997-6003, 2013.

[30] E. M. FLANIGEN, H. KHATAMI, and H. A. SZYMANSKI, "Infrared Structural Studies of Zeolite Frameworks," no. 28, pp. 201-229, 1974.

[31] A. Guzman, I. Zuazo, A. Feller, R. Olindo, C. Sievers, and J. A. Lercher, "On the formation of the acid sites in lanthanum exchanged X zeolites used for isobutane/cis-2butene alkylation," Microporous mesoporous Mater., vol. 83, no. 1-3, pp. 309-318, 
2005.

[32] Z. Le, L. I. Qiang, Q. I. N. Yucai, and Z. Xiaotong, "Investigation on the mechanism of adsorption and desorption behavior in cerium ions modified Y-type zeolite and improved hydrocarbons conversion," J. Rare Earths, vol. 34, no. 12, pp. 1221-1227, 2016.

[33] X. Du, X. Gao, H. Zhang, X. Li, and P. Liu, "Effect of cation location on the hydrothermal stability of rare earth-exchanged Y zeolites," CATCOM, vol. 35, pp. 1722, 2013.

[34] E. F. T. Lee and L. V. C. Rees, "Calcination of cerium ( Ill ) exchanged Y zeolite," no. Ill, 1986.

[35] Y. Shanqing, T. Huiping, D. Zhenyu, Z. Yuxia, and L. Jun, "Different Influences of Lanthanum and Cerium on Stability of Y Zeolite and Their DFT Calculations," vol. 13, no. 1, pp. 16-23, 2011.

[36] M. Thommes et al., "Physisorption of gases, with special reference to the evaluation of surface area and pore size distribution (IUPAC Technical Report)," Pure Appl. Chem., vol. 87, no. 9-10, pp. 1051-1069, 2015.

[37] S. Komaty et al., "A facile route toward the increase of oxygen content in nanosized zeolite by insertion of cerium and fluorinated compounds," Molecules, vol. 23, no. 2, 2018.

[38] X. Liu, S. Liu, and Y. Liu, "A potential substitute for CeY zeolite used in fluid catalytic cracking process," Microporous Mesoporous Mater., vol. 226, pp. 162-168, 2016.

[39] S. C. Laha, P. Mukherjee, S. R. Sainkar, and R. Kumar, "Cerium containing mcm-41type mesoporous materials and their acidic and redox catalytic properties," J. Catal., vol. 207, no. 2, pp. 213-223, 2002.

[40] M. Guo, J. Lu, Y. Wu, Y. Wang, and M. Luo, "UV and visible Raman studies of oxygen vacancies in rare-earth-doped ceria," Langmuir, vol. 27, no. 7, pp. 3872-3877, 2011.

[41] Y. Peng et al., "Investigation of the Poisoning Mechanism of Lead on the CeO2瑖 WO3 Catalyst for the NH3-SCR Reaction via in Situ IR and Raman Spectroscopy Measurement," Environ. Sci. Technol., vol. 50, no. 17, pp. 9576-9582, 2016.

[42] C. R. Moreira, M. Schmal, and M. M. Pereira, "The effect of cerium introduction on vanadium-USY catalysts," in Studies in Surface Science and Catalysis, vol. 143, Elsevier, 2000, pp. 915-923.

[43] J. Li et al., "Tuning of acidity in CeY catalytic cracking catalysts by controlling the migration of $\mathrm{Ce}$ in the ion exchange step through valence changes," J. Catal., vol. 329, pp. 441-448, 2015.

[44] V. A. Online, "A DFT + U study of NO evolution at reduced CeO 2 (110) †," vol. 2, no. 110, pp. 16904-16908, 2014.

[45] E. Ito et al., "Selective reduction of NO, with ammonia over cerium-exchanged 
mordenite," vol. 4, no. 94, pp. 95-104, 1994.

[46] A. Akah, "Application of rare earths in fluid catalytic cracking: A review," J. Rare Earths, vol. 35, no. 10, pp. 941-956, 2017.

[47] X. Du, X. Gao, H. Zhang, X. Li, and P. Liu, "Effect of cation location on the hydrothermal stability of rare earth-exchanged Y zeolites," Catal. Commun., vol. 35, pp. 17-22, 2013. 